\title{
Russian RBMK Reactor Design Information
}

Prepared by

Russian Academy of Science

Nuclear Safety Institute

Moscow, Russia

under Basic Ordering Agreement No. 190290-A-I1

November 1993

Prepared for

the U.S. Department of Energy

under Contract DE-AC06-76RLO 1830

Pacific Northwest Laboratory

Richland, Washington 99352

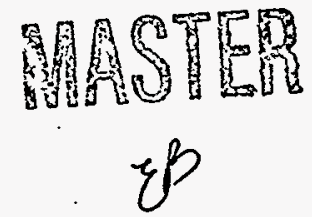




\section{DISCLAIMIER}

Portions of this document may be illegible in electronic image products. Images are produced from the best available original document. 


\section{Executive Summary}

This document concerns the systems, design, and operations of the graphite-moderated, boiling, water-cooled, channel-type (RBMK) reactors located in the former Soviet Union (FSU). The Russian Academy of Sciences Nuclear Safety Institute (NSI) in Moscow, Russia, researched specific technical questions that were formulated by the Pacific Northwest Laboratory (PNL) and provided detailed technical answers to those questions. The Russian response was prepared in English by NSI in a questionand-answer format. This report presents the results of that technical exchange in the context they were received from the NSI organization.

Pacific Northwest Laboratory is generating this document to support the U.S. Department of Energy (DOE) community in responding to requests from FSU states, which are seeking Western technological and financial assistance to improve the safety systems of the Russian-designed reactors.

This report expands upon information that was previously available to the United States through bilateral information exchanges, international nuclear society meetings, International Atomic Energy Agency (IAEA) reactor safety programs, and Research and Development Institute of Power Engineering (RDIPE) reports.

The response to the PNL questions have not been edited or reviewed for technical consistency or accuracy by PNL staff or other U.S. organizations, but are provided for use by the DOE community in the form they were received. 



\section{Contents}

Executive Summary $\ldots \ldots \ldots \ldots \ldots \ldots \ldots \ldots \ldots \ldots \ldots \ldots \ldots \ldots$ iii

Group I Questions: Instrumentation and Control Systems for RBMK . . . . . . . . . 1

1. Description Documentation for Instrument and Control Systems ...... . 1

2. Control Rod Insertion Time $\ldots \ldots \ldots \ldots \ldots \ldots \ldots \ldots \ldots \ldots \ldots$

3. Computer Systems for Plant Control $\ldots \ldots \ldots \ldots \ldots \ldots \ldots \ldots$

4. I\&C Protection in Accident Environments ............... 8

5. Redundant Instrumentation . . . . . . . . . . . . . . . . 9

Group II Questions: RBMK Primary System and Reactor Core $\ldots \ldots \ldots \ldots \ldots$

1. Water Level Control in Steam Drum ... . . . . . . . . . . 10

2. Steam Drum Design Features $\ldots \ldots \ldots \ldots \ldots \ldots$

3. Fuel Assembly Design Features $\ldots \ldots \ldots \ldots \ldots \ldots \ldots$

4. Graphite Rings and Pressure Tube Interface ... . . . . . . . . . 17

5. Graphite Heat Removal . . . . . . . . . . . . . . . 17

Group III Questions: RBMK Design/Operation $\ldots \ldots \ldots \ldots \ldots$

1. Steam Drum Level Measurements ................... 19

2. Method of Drum Level Control ..................... 19

3. Feedwater Return Pump Characteristics $\ldots \ldots \ldots \ldots \ldots \ldots \ldots \ldots$

4. Makeup Control to Reactor Loop ................. 28

5. Maximum Turbine Bypass .................... 34

6. Steam Drum Pressure Control $\ldots \ldots \ldots \ldots \ldots \ldots \ldots \ldots \ldots$

7. ECCS Pump Characteristics .................. 35

8. Full Open Area of the Channel Orifice $\ldots \ldots \ldots \ldots \ldots \ldots$ 



\section{Figures}

1. Control Rod Design Changes $\ldots \ldots \ldots \ldots \ldots \ldots \ldots \ldots \ldots \ldots \ldots \ldots \ldots \ldots$

2. Steam Drum Level Measurement Principle $\ldots \ldots \ldots \ldots \ldots \ldots \ldots \ldots \ldots .12$

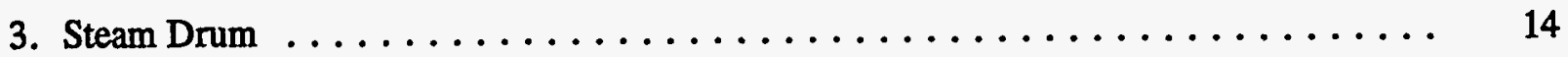

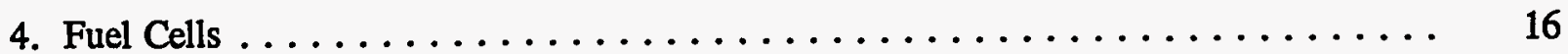

5. Graphite Rings and the Pressure Tube Interface $\ldots \ldots \ldots \ldots \ldots \ldots \ldots \ldots$

6. Level Vessel for First Generation Units $\ldots \ldots \ldots \ldots \ldots \ldots \ldots \ldots \ldots \ldots$

7. The Internals of the Steam Drum for First Generation Units $\ldots \ldots \ldots \ldots \ldots \ldots 21$

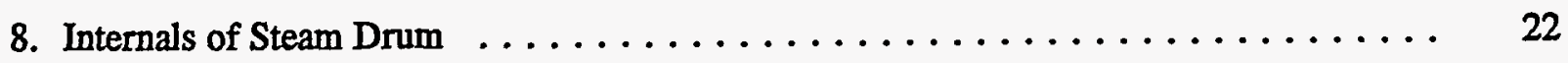

9. Steam Drum for First Generation Units $\ldots \ldots \ldots \ldots \ldots \ldots \ldots \ldots \ldots \ldots \ldots \ldots \ldots$

10. The Internals of the Steam Drum for Second Generation Units $\ldots \ldots \ldots \ldots \ldots 24$

11. Level Vessel for Second Generation Units $\ldots \ldots \ldots \ldots \ldots \ldots \ldots \ldots \ldots . \ldots \ldots$

12. Steam Drum for Second Generation Units $\ldots \ldots \ldots \ldots \ldots \ldots \ldots \ldots \ldots .26$

13. Feedwater Pump Curve $\ldots \ldots \ldots \ldots \ldots \ldots \ldots \ldots \ldots \ldots \ldots \ldots \ldots \ldots \ldots \ldots \ldots$

14. Simple Heat Scheme $\ldots \ldots \ldots \ldots \ldots \ldots \ldots \ldots \ldots \ldots \ldots \ldots \ldots \ldots \ldots \ldots \ldots \ldots \ldots$

15. Makeup and Outflow Scheme $\ldots \ldots \ldots \ldots \ldots \ldots \ldots \ldots \ldots \ldots \ldots \ldots, 32$

16. ECCS Simple Scheme $\ldots \ldots \ldots \ldots \ldots \ldots \ldots \ldots \ldots \ldots \ldots \ldots \ldots \ldots \ldots \ldots \ldots \ldots$

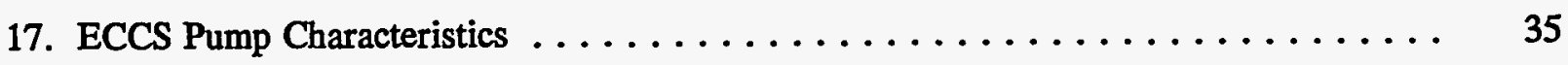

18. The Supply/Demand Curve for the ECCS of First Generation Units . . . . . . . 36

19. The Supply/Demand Curve for the ECCS of Second Generation Units . . . . . . . 37

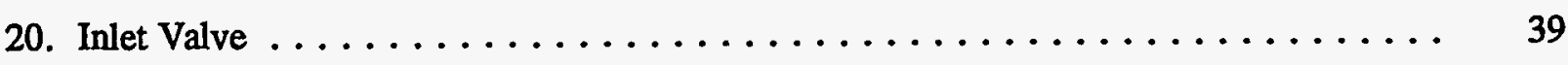

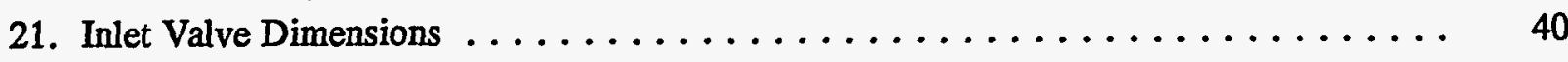




\title{
Russian RBMK Reactor Design Information Questions and Answers
}

This document concerns three categories of questions regarding the RBMK reactor: instrumentation and control (I\&C) systems; the reactor core and the primary system; and the design and operations of the plant. The first group of questions, regarding I\&C systems, follows below.

\section{Group I Questions: Instrumentation and Control Systems for RBMK}

Question 1: Does "system description" documentation exist for I\&C systems of RBMK reactors?

\begin{abstract}
A system description would contain logic diagrams, piping and instrumentation drawings, detector locations, setpoints, block diagrams, instrument loop diagrams, and $a$ text description of the system.
\end{abstract}

If system descriptions exist, may we have copies?

If system descriptions do not exist, is there interest in preparing them for design documentation or training aids?

\section{Answer:}

The required system description documentation is available at the nuclear power plants (NPPs). Operation I\&C schemes include the following:

- logic diagrams

- piping and instrumentation drawings

- detector locations.

Moreover, there are so-called "setpoint cards."

It is the most reliable documentation with all introduced changes and improvements. This documentation is used for simulator development and is also available in the following project organizations (each has its own part of the whole project):

- Moscow Department of "Atomenergoproject" (MO AEP) 
- Leningrad Institute of "Atomenergoproject" (LI AEP)

- RDIPE (NIKIET).

A full set of operational documentation is available only at each NPP. Copies of the documents can be given only on agreement with Operational Organization (Rosenergoatom).

Question 2: $\quad$ Regarding rod insertion time:

What design changes have been implemented, and what design changes are planned to improve rod insertion time?

Is response-time surveillance testing performed on the reactor protection system (time from change in process parameter to start of rod motion into core)?

What are typical response times and control rod insertion times?

What are the plans to improve the response time and control rod insertion time?

\section{Answer:}

The implemented design changes include 1) control rod changes, 2) control rod drive changes, and 3) I\&C control circuit changes. (See Figure 1.) Each change is explained below.

\section{Explanation of Control Rod Changes}

The objectives of the implementation of control rod changes are to increase physical weight (BETA $\mathrm{EFF}$ ), to increase velocity efficiency (BETA EFF/sec), and to exclude the possibility of a reactivity increase in any point of rod movement in the channel.

Implemented changes are as follows:

1. In each RBMK-unit, a group of control rod channels with rods and rod drives of new design was separated. The rods are called "fast-acting control rods" (BAZ). (Sb. 2505.00.000 - BAZ).

\section{Summary:}

- Absorber length was increased.

- Cooling water in control rod channels was replaced by $\mathrm{N}_{2}$. Cooling of channel wall is realized by a water film. 


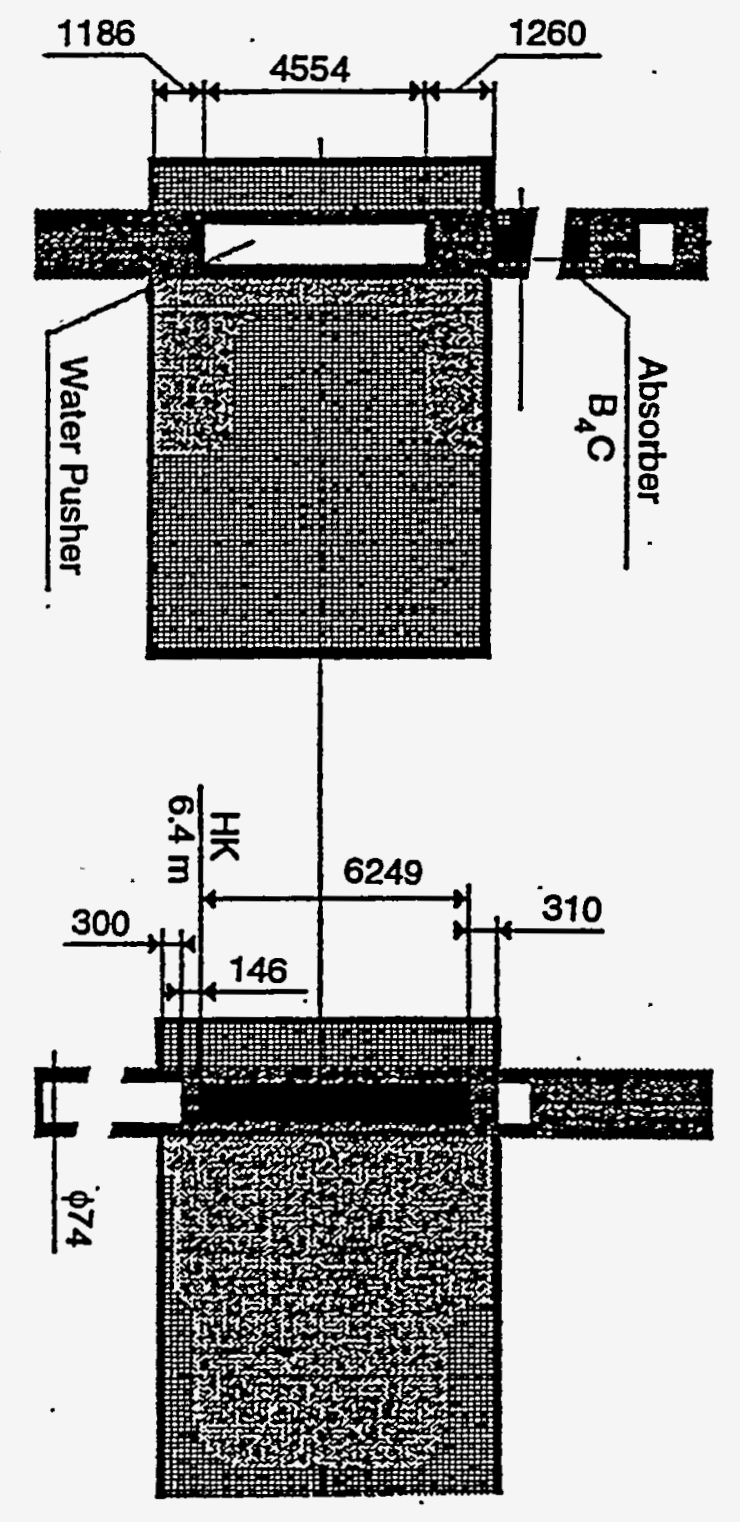

Figure 1. Control Rod Design Changes

- No more changes are planned.

2. The outdated rods (Sb. 1971.00.000) inserted from the top were replaced with new ones (Sb. 2091.00.000). 


\section{Summary:}

- Telescope block was extended.

- Absorber length was increased.

- Planned changes: replace the existing rods with skirt-type rods (Sb. 2477).

3. The outdated rods inserted from the bottom were replaced with new ones ( $\mathrm{Sb}$. 2093.00.000).

\section{Summary:}

- Absorber length was increased.

- No more changes are planned.

4. The new skirt-type rods were worked out (Sb. 2477.00.000).

\section{Summary:}

- The length of water pushers was increased.

- The new skirt-type section was added to an absorber.

- This section is an external part of the telescope adapter. Its internal part is the top section of the water pusher.

- Dozens of such rods are being now tested at Kursk NPP and Leningrad NPP.

- Planned changes: replace rods with these new ones (Sb. 2091.00.000).

\section{Explanation of Control Rod Drive Changes.}

The objective of changing the control rod drive is to increase scram velocity efficiency (BETA $\mathrm{EFF} / \mathrm{sec})$.

The implemented changes are as follows:

1. The flag switch was introduced for rods (Sb. 2091.00.000). It activates electrodynamic braking after the rod has passed $3 \mathrm{~m}$. Before the changes were implemented, the braking action was activated immediately after the start-up of rod movement. Because of this change, the control rod insertion time was decreased from 18 to $12-14 \mathrm{sec}$. 
2. For "fast-acting rods," a new drive was introduced with the reduced gear ratio. The braking action starts at the end of rod movement. Because of this change and the gas-type water pusher, the control rod insertion time decreased to between 2 to 5 sec.

\section{Explanation of I\&C Control Circuit Changes}

The objectives of the I\&C circuit changes are to increase the reliability of the reactor protection system and to decrease the response time. The implemented changes are as follows:

1. More severe setpoints were brought into use:

- The setpoint "scram due to superatmospheric pressure increase in core space" was reduced from 2000 to $750 \mathrm{~mm} \mathrm{H}_{2} \mathrm{O}$.

- The setpoint "scram due to superatmospheric pressure increase in primary circuit room" was decreased from 500 to $200 \mathrm{~mm} \mathrm{H}_{2} \mathrm{O}$ for second generation units and to $70 \mathrm{~mm} \mathrm{H}_{2} \mathrm{O}$ for first generation units.

2. The outdated instrumentation in the reactor protection system has been replaced with modern equipment (new pressure and pressure differential instrumentation "SAPFIR," the new amplifier "K-140"). Contact power relays (BVRK) in the rod-driving system have been replaced with contactless relays (BUSP). New amplifiers "Alexandrit" have also been established.

This work is being conducted in compliance with the reconstruction schedule.

3. In the protection system "scram due to water level decrease in emergency tank and pressure decrease in distribution header of control rod cooling system," logic element "and" was changed into "or" variant.

4. Test programs of operational surveillance take into account only the fact of emergency signal pass to scram and its compliance with setpoints.

Studies on the response time are conducted only in the period when systems are put into operation, according to special programs. The expert commission usually consists of representatives of research and design institutes and NPP personnel. They use special instrumentation.

At Kursk NPP, such a method was used while measuring the response time of rod motion start into core due to neutron flux parameter changes. This work was done during implementation of a fastacting protection system. In this case, the signal from neutron flux imitator was sent into the circuit instead of the signal of neutron detector. An investigation of the response time was conducted with loop-type oscillograph. The following signals were imitated: 
- the signal "scram due to neutron power increase"

- the signal "scram due to increase of neutron power speed."

Investigations determined that the response time of the first protection system is more effective $(<0$ to $3 \mathrm{sec})$. The second protection system is more inertive $(<0$ to $8 \mathrm{sec})$. The data close to these quantities are used in "Technical Safety Assurance."

\section{Sources:}

Technical Safety Assurance of Stage 2 Reactor Facility at Kursk NPP.

The Commission Report on Testing of Reactor Protection System at Kursk NPP, 1989.

Question 3: Is plant control heavily dependent on computer systems? What is the level of technology of RBMK computer systems? Discrete components? Large scale integrated circuits?

McDermott built a plant in FSU about 5 years ago to produce the Bailey Network 90 distributed process control systems. Have any of these components been used for instrumentation/computer design changes in RBMKs? If these control systems are being used in RBMKs, what systems are they controlling?

Answer:

At all NPP operating units with RBMK-1000 reactors [Leningrad NPP (LNPP); Kursk NPP (KNPP); Smolensk NPP (SNPP); Chernobyl NPP (ChNPP)], there is a standard data-processing system (DPS) "SCALA", which consists of high- and low-level electronic computers. DPS "SCALA" carries out the following informational functions:

- state of switching devices (switches, valves)

- deviations from setpoints (alarm-signals)

- parameter values on call

- deviation values

- parameter registration on recoders, printers, and magnetic tapes

- calculations of channel power, bundle exposure, and safety factors up to departure from nucleate boiling. 
The "SCALA" computer system technology dates to the late 1960s. (It is the former USSR second generation product.) The element base consists of transistors and ferrite main memory. External memory is a tape drive.

This computer system monitors approximately 12,000 parameters. About 8000 parameters are monitored individually or directly by detectors through switched circuits. Among them, about 2000 parameters are discrete; the rest are analog.

In addition, the automated system monitors nearly 4000 parameters connected with operational limits or operational safety margins (channel power, safety factors up to departure from nucleate boiling, fluxtilt coefficients, and reactivity margins). Calculation cycles of these critical functions exceed $30 \mathrm{~min}$.

The system of centralized control will be implemented at Unit 1 RBMK-1000 during reconstruction and at Unit $5 \mathrm{KNPP}$, which is under construction now. The system is based on a distributed network with mini- and macro-computers. Homemade macroprocessors (KR-580 and KR-1810) used in these systems are analog to INTEL-8080 and INTEL-8086.

At Ignalina NPP (INPP) with RBMK-1500 reactor, a standard three-level DPS "TITAN" with improved performances is installed. At the upper level of this system, there are 9 computers of SM-2M type (third generating middle-scale integrated circuits). In all, the system includes 100 computers. In this DPS, the "PRIZMA" cycle takes about $3 \mathrm{~min}$, and updating of all measured values (more than 12,000 analog and more than 20,000 digital) takes less than $10 \mathrm{sec}$.

At INPP first unit, an expert system of operative diagnostics (for operator support) "SPRINT" has been in operation since 1986. The system is realized in the real-time scale (computer SM-2M). The aim of this system is to improve the safety, reliability, and efficiency of NPP operations, by

- detecting automatic faults and malfunctions at an early stage, in all main process systems

- displaying diagnostics results in a compact and suitable form for operating staff (all this information is archived)

- providing instructions for isolation of malfunctions (according to process rules, operation manuals, etc).

By 1991 the diagnostics systems had been installed at all 27 main unit process systems. "SPRINT" covers all measured parameters of the generating units and has detected more than 10,000 malfunctions. The knowledge base includes more than 30,000 rules. According to the most recent test report, only 20 of more than 1000 (standard and not standard) operating conditions were wrongly diagnosed. There were strong interferences: one third of the detectors in some systems failed. These problems were also detected. 
At the INPP first unit and at the SNPP third unit, an improved version of the "SPRINT" system has been in operation since 1992. This version is a set of codes for IBM PC "DIAG," developed by NSI.

We do not have any information on usage of McDermott Plant production.

Question 4: $\quad$ Are I\&C systems qualified for harsh post-accident environments of high temperatures and humidity? If the instrumentation is qualified, what procedures are used to qualify the I\&C systems?

Answer:

I\&C equipment of safety significant systems made in accordance with harsh standards of "Technical Conditions" (TC) is qualified both at the manufacturer and at the NPP. Qualification testing is carried out at the manufacturer by representatives of Regulatory Body (Gan), who check equipment compliance with TC criteria. The standards of checking are more severe (level 5) in comparison with ones in other branches of industry. In case of positive results, a special stamp "For NPP" is put into certificate.

A full initial check of equipment compliance with TC and design requirements is carried out at the NPP before performance (western term-Quality Control System).

The main principle of I\&C protection against a harsh post-accident environment (high temperature and humidity) in significant safety systems is to locate the electrical components of the equipment in separate boxes isolated from high-pressure tubes and a facility.

If it is impossible to remove an electro-induction detector out of the "hot" room (e.g., channel flow detector), it is tested with a cable in a special oven.

Question 5: $\quad$ Please describe how redundant instrumentation, control systems, and electrical system designs consider separation for fire or accident conditions.

Answer:

\section{Redundant Instrumentation}

Scram equipment (one division) includes the following:

- in start-up range

- four circuits on power exceedance (logic 2 from 4)

- three circuits on overspeeding of power increase (logic 2 from 3) 
- in working range

- three circuits on overspeeding of power increase (logic 2 from 3)

- eight circuits on power exceedance (two logic groups 1 from $4+1$ from 4).

After reconstruction there will be two divisions available. Each division will be installed in separate rooms. Circuits of each division (devices and cables) will also be separated and either located in various rooms or separated with fire-resistant walls and barriers.

\section{Technological Protections}

The most important trips activating at LOCA fast-scram system (scram on pressure increase in reactor vessel, scram on pressure increase in primary circuit rooms), have divisions of detectors, cables, and instrumentation.

Each division is located in separate rooms far away from other divisions. Each division has three to four circuits (logic 2 from 3 or 2 from 4).

Other trips with two divisions will be provided during the coming reconstruction.

\section{Control System}

The control of the neutron flux system is fully supported by the stand-by system (from detectors to actuators). The same stand-by system is used for SB level control.

\section{Electrical System}

All scram and technological equipment, as well as the most significant controllers, have category "A" feeding (essential, stand-by autonomous from diesel or batteries).

\section{Emergency Core Cooling System}

The instrumentation used in first generation units is of the same type used in technological protection systems (SD level primary circuit room pressure). Second generation units have special instrumentation with three sub-systems feeding into various rooms.

Each of the sub-systems feeds one separate, fully autonomous emergency core cooling system (ECCS) circuit (50\% of capacity). 


\title{
Group II Questions - RBMK Primary System and Reactor Core
}

\author{
Question 1: How is the water level in the steam drum controlled?
}

a) As we currently understand the system, feedwater returning from the turbine condensers is throttled to control level. What type of feedback control is used? Is it a single-element control based on drum level; a three-element control using steam flow, feedwater flow, and level; or something else?

\section{Answer:}

Drum level is controlled by the feedwater return via control feed valves. Each independent, halfsection of the primary circuit has its own drum level control circuits (level and flow detectors and five control values). Three of the valves are used in operating of high power level conditions (over $20 \%$ ), and the others (of less productivity) are used in starting and breaking conditions.

When the automatic level controller is in operation, the three main valves work as follows: the first one is adjusted by the automatic controller, the second one is on duty, and the third one is in reserve. An automatic switch from the controlled valve to the valve in duty will take place when the controller fails or when the valve reaches extremes. The reserved valve is switched on manually. In starting conditions, the starting control valves are in operation. After they have been opened to preset limits, the switch to the main valves occurs. If the safety control comes into action, the starting valves will become controlled. During fast transient or fast control unloading (one turbine trip out of two, one main circulation pump trip out of three, a drum level decrease to the setpoint of $500 \mathrm{~mm}$, a feedwater flow decrease to $70 \%$ from the initial rate), the duty valve automatically switches into automatic control along with the first one.

The energy range system is controlled by a three-impulse scheme. An average signal from differential manometers, which measure the level in two drums of a primary circuit half-section, is used as a level signal. For steam-flow rate measurements, narrowing devices and differential manometers are installed in each (of the four) main steam lines. The feedwater flow rate signal comes from differential manometers installed in feedwater pipelines.

At starting and braking conditions (at $20 \%$ powèr and below) when water and steam flow rate signals are not reliable, the system is controlled via the level signal only.

As hydraulic regimes of a drum in one-half section of primary circuit may differ slightly from those in another drum, special water and steam connectors are installed for drum water leveling.

The three-pulse feed controller itself is an isodrom one. However, the presence of the feedback on the feedwater flow rate turns it into a proportional one, because the difference of the feedwater flow 
rate in transient processes is practically proportional to the sum of differences of the level and of the steam flow rate, multiplied by the appropriate factors. Differences from proportionality may occur only because of limits caused by the rate of the control valves displacement.

\section{b) Is the steam drum level measurement compensated for the frothing action, or is it simply a differential pressure measurement that would represent a "col- lapsed" liquid level?}

\section{Answer:}

The device for steam drum level measurement includes a level vessel, signal (impulse) tubes, differential manometer, and electric instrumentation (Figure 2).

The level vessel is located in the "cool" room and connected to the steam drum through the room wall. The signal tubes $(50 \mathrm{~mm})$ connect the drum "steam" side with the vessel top and drum "water" side with the vessel bottom. The level vessel consists of two chambers. Internal chambers are filled to the top due to natural circulation.

External chamber level is connected with the lowest part of the drum. Signal tubes are attached to the differential manometer from the bottom internal chamber " + " output and from the bottom external chamber "-" output. The level difference between internal and external chambers determines drum level. Figure 2 illustrates the principle of measurement.

There are two types of detectors. A "big detector" activates the control of drum level and the emergency protection system (scram, fast power decrease, ECCS). Its scale is $\pm 800 \mathrm{~mm}$ from the drum geometrical axis. It also measures water inventory in the primary circuit.

A "small detector" (its scale is $\pm 315 \mathrm{~mm}$ from the rate level; 65 to $695 \mathrm{~mm}$ from geometrical axis) measures the level of steam-water mixture on the drum grill. It is an indicator of steam moisture that determines the operational limit of drum level. All level instrumentation measures weight level because the temperature in the room is normal where level vessel is located. This factor is provided by natural circulation and the froth influence.

The level signal comes to the controller from a "small detector." A change in the void fraction below the lower connection point results in a change of the weighting column above this connection point and in a change of the level detector signal. Only level changes caused by variances of the void fraction in the interspace between connection points do not influence the level detector signal readout and result in an error of measurement. As the level meter base is much lower than the height of the steam-water section of the circuit (about $10 \mathrm{~m}$ ), the changes of the void fraction in the interspace between connection points may be neglected, and level meter is considered to display the true void fraction. Changing of steam content volume in the range of zero to the nominal value of $30 \%$ (at constant level meter signal) results in true level changing of about $100 \mathrm{~mm}$, which is quite tolerable. 


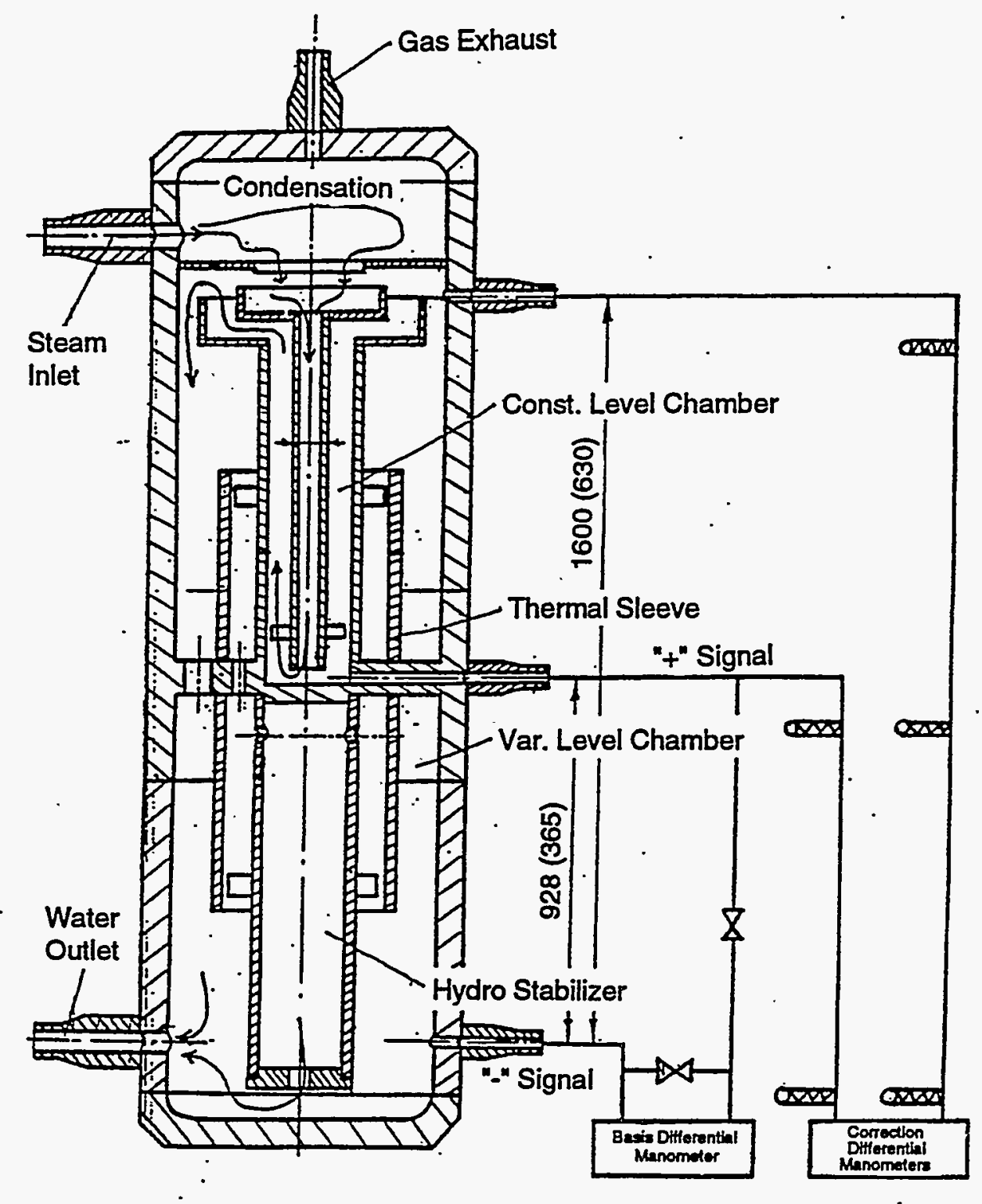

Figure 2. Steam Drum Level Measurement Principle 
c) Where does makeup for reactor coolant inventory control enter the cooling system? Is it injected at the turbine condensers, the deaerator, the feedwater pumps, reactor coolant pump suction, steam drum, etc.?

Answer:

Makeup of the circuit is accomplished by makeup water flow to the turbine condenser. If the level in the condenser is exceeded, makeup water is conveyed to the deaerator. (If fast control unloading comes into action, makeup water is always conveyed to the deaerator.) Makeup water flow is automatically controlled by using a deaerators level signal.

Question 2: $\quad$ Please provide a sketch of the internals of the stream drum. How much mixing there is between the hot coolant from the core and the cold feedwater return?

Is there a sparger at the bottom of the drum to disperse the cooler water from the feedwater return pumps? Does the feedwater enter the steam drum at the bottom of the drum?

Are there any internal baffles or thermal sleeves located between the feedwater return (inside the drum) and the hot, two-phase coolant from the reactor outlet, where it enters the steam drum?

Do the core outlet tubes penetrate significantly into the steam drum? (Do they penetrate for $10 \mathrm{~cm}, 20 \mathrm{~cm}, 30 \mathrm{~cm}$ or more into the drum, or are they essentially flush with the inside of the drum?)

Answer:

The steam drum (Figure 3) comprises a horizontal cylindrical vessel 2 with an inner diameter of $2300 \mathrm{~mm}$ and length of $30.7 \mathrm{~m}$. This cylinder has the following fittings: 432 inlet fittings 10 (dia = $70 \mathrm{~mm}$ ) for steam-water flux from the reactor channels, 14 steam outlet fittings 8 (dia $=300 \mathrm{~mm}$ ), 12 circuit water outlet fittings 9 (dia $=300 \mathrm{~mm}$ ), 1 feedwater inlet fitting 7 (dia $=400 \mathrm{~mm}$ ), 5 fittings $($ dia $=300 \mathrm{~mm}$ ) for steam connectors between 2 adjacent drums, 8 fittings (dia $=50 \mathrm{~mm}$ ) for level meter connections, 14 fittings ( $\mathrm{dia}=10 \mathrm{~mm}$ ) for water and steam sampling and pressure measurement.

The steam-water mixture inlet fittings are set in four rows. Each row is located at generatrix in the lower part of the drum and is symmetric about the lower generatrix. The inner parts of the fittings are flush-mounted with the inner surface of the drum. Steam-water mixture comes into container 6 , where kinetic energy of the flow is quenched by the baffles, and steam is directed upwards to minimize its capture by the down pipes. Then the steam passes through the submerged perforated shield 3 and babbling layer above it. After that, the steam is dried via gravitational separation in steam space and 

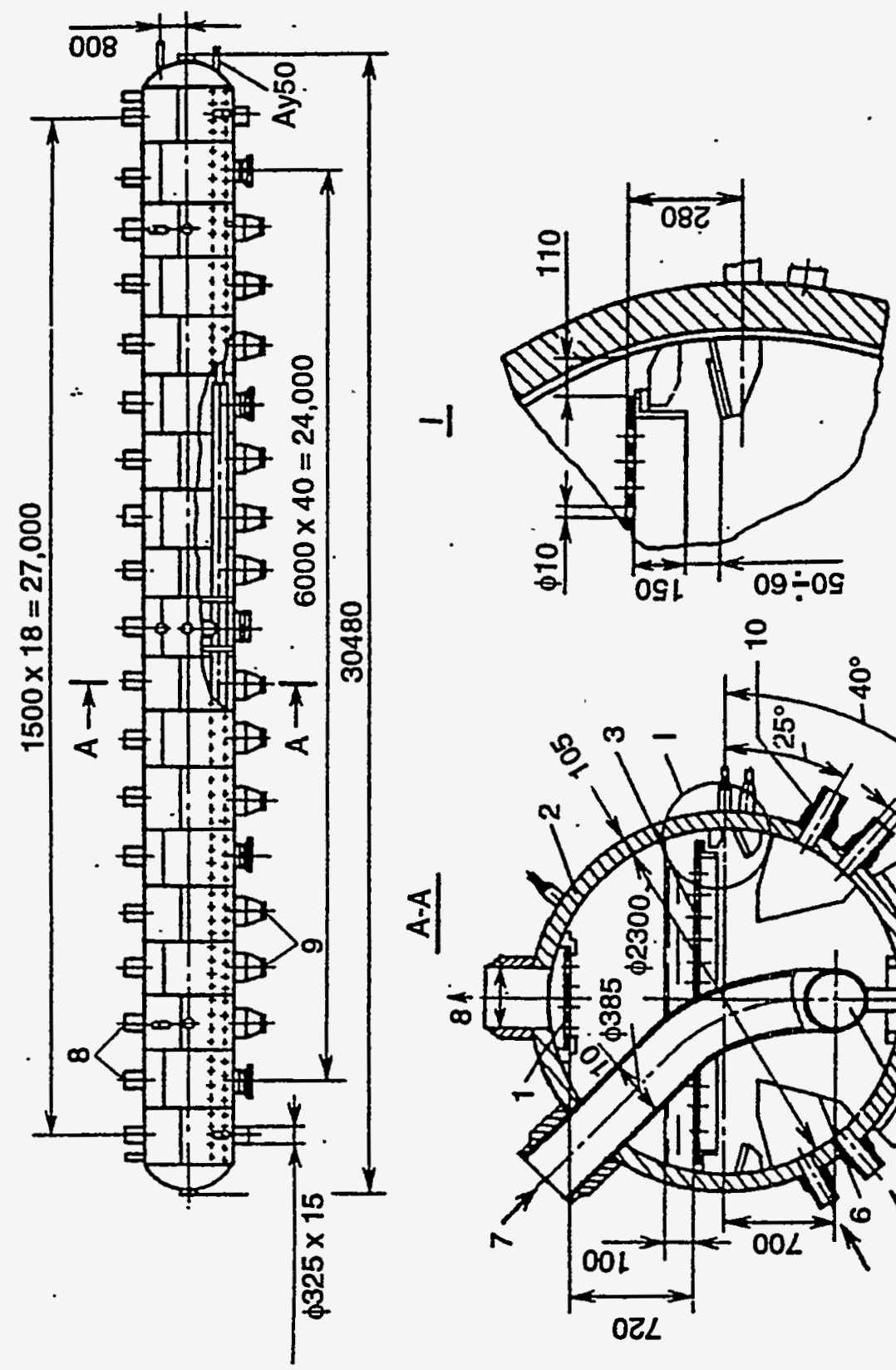

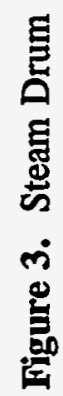

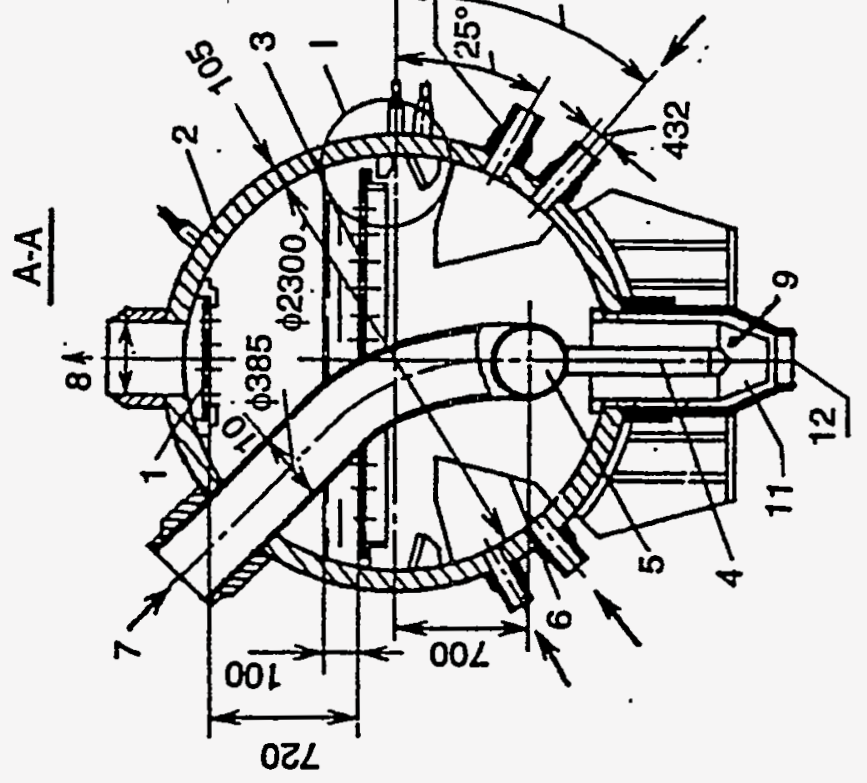


finally comes through perforated shield 1 to the outlet steam fitting. Water pours out from the containers and comes into water outlet fittings, located in a row along the lower generatrix of the drum, where it is mixed with feedwater and is fed into main circulating pumps.

Feedwater is supplied through a pipe line 7, located in the steam space in the upper part of the drum (the pipe axis is inclined $45^{\circ}$ with respect to vertical line), and enters the horizontal water distribute pipe 5 (dia $=300 \mathrm{~mm}$ ), located in the lower part of the water space along the whole length of the drum. Perforated mixers 4 branch out from the reservoir to each down water outlet fitting 9 . The down pipes in the points of the connection to the drum (at length about $1 \mathrm{~m}$ ) grow wider and form a reservoir for water mixing. Thus, feedwater enters directly to the down pipes and avoids drum water. For minimization of thermal stress, the section where hot and cold waters are mixed is thermally shielded from the pressure-bearing wall by thermal sleeve 11. A fitting of special design is used for connection of the feedwater pipe to the drum for additional diminishing of thermal stresses.

Question 3: $\quad$ Can we get detailed fuel assembly drawings/dimensions that include rod spacing (including spacing from the carrier rod)? What are the spacer design details? What are the design tolerances for rod bow? Is the carrier rod for the affected assembly solid or hollow, and what are the dimensions of the carrier rod?

Answer:

Reactor core (diameter is about $12 \mathrm{~m}$ and height is $\mathbf{7 ~ m}$ ) is situated in the central part of the graphite masonry and is formed by zirconium process channels (outer diameter is $88 \mathrm{~mm}$ and wall width is $4 \mathrm{~mm}$ ), passing along the axis of the graphite column, forming square grid with spacing 250 by $250 \mathrm{~mm}$. Zirconium CPS channels (diameter is 88 by $3 \mathrm{~mm}$ ) are installed in this grid. Altogether there are 2488 graphite columns in the core. Of them, 1693 (1st phase) and 1661 (2nd phase) have process channels; 179 (1st phase) and 211 (2nd phase) have CPS channels; 12 have energy generation control detector channels; and 4 have fission chamber channels.

In the process channels, there are two types of fuel cells (Figure 4). The first type of fuel cell has a channel (dia $=7 \mathrm{~mm}$ ) in the central carrier zirconium rod (tube) for installation of radial energy distribution detectors, gamma chambers, absorbing rods, or local automatic control system detectors; outer diameters of all devices located in the channel are $6 \mathrm{~mm}$. The second type of fuel cell does not have a channel in the carrier rod. The external diameter of carrier rod is $13 \mathrm{~mm}$; carrier tube is $15 \mathrm{~mm}$.

A fuel cell consists of 2 fuel assemblies mounted on the central rod (tube). Each fuel assembly includes 18 fuel element rods (length is $3.46 \mathrm{~m}$ at $20^{\circ} \mathrm{C}$ ), a frame, and mounting hardware. 

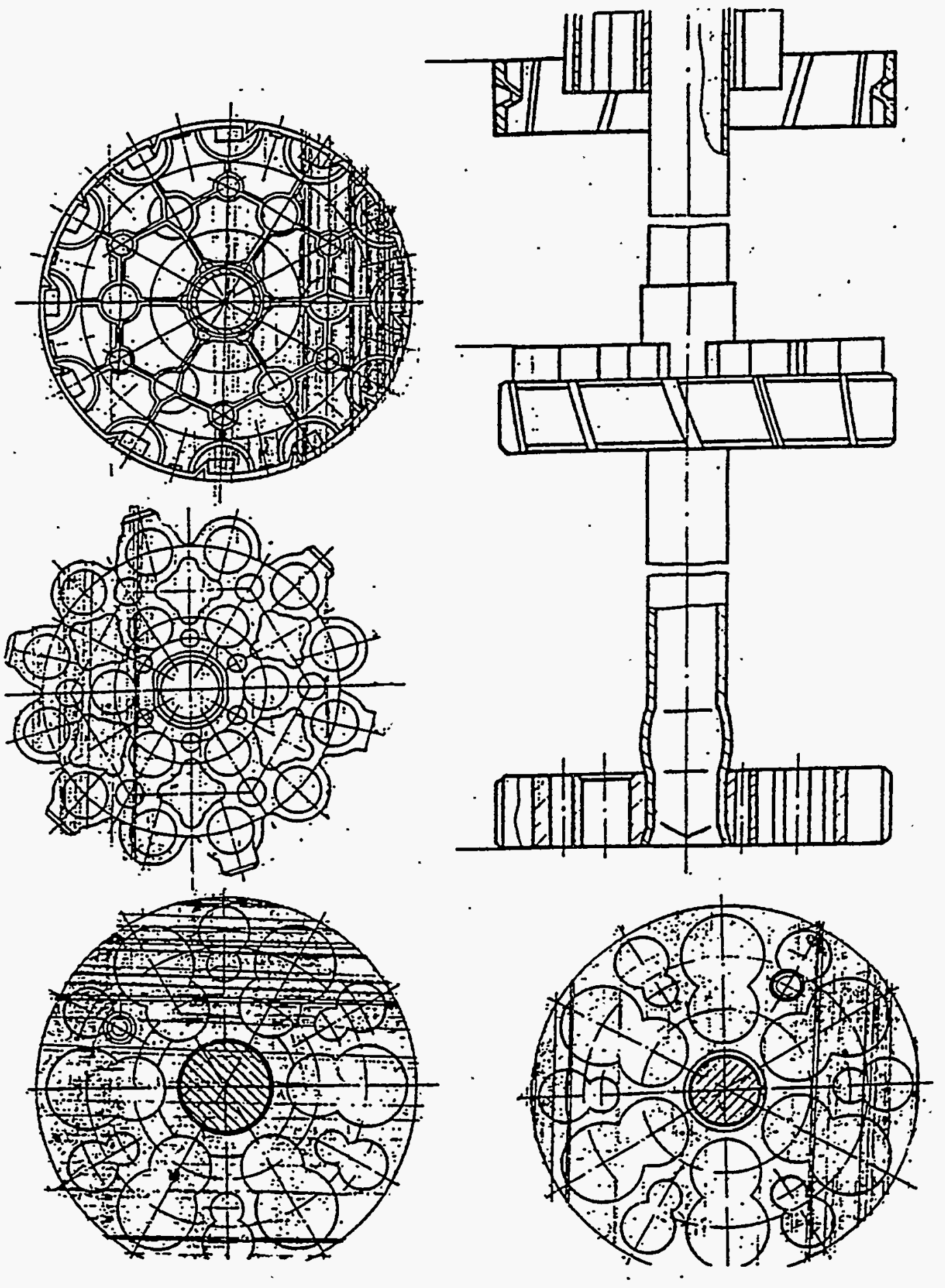

Figure 4. Fuel Cells 
In each fuel assembly, all fuel elements are fasten in one terminal and in 10 intermediate space steel grids, mounted on the central zirconium tube. Their axes are arranged in 2 circles, diameter $32 \mathrm{~mm}$ (6 fuel elements) and $62 \mathrm{~mm}$ (12 fuel elements).

In each fuel cell, there is an axial clearance between both fuel assemblies, not less than $20 \mathrm{~mm}$, providing for thermal expansion of the elements. The diameter and thickness of the fuel element zirconium cover are 13.5 by $0.9 \mathrm{~mm}$.

In accordance with factory test data, the tolerable deformation of fuel elements between the spacer grids is $0.3 \mathrm{~mm}$ for $300 \mathrm{~mm}$.

Question 4: Can we get detailed drawings/dimensions for the graphite rings and the pressure tube interface? We currently have only simple sketches, and these don't indicate tolerance for fit.

\section{Answer:}

Answers are clear from the picture (Figure 5).

Question 5: We have estimates indicating that graphite heat is 5.5\% of the core thermal power, and we understand that there is no graphite cooling system. Is this heat primarily removed by the coolant in the pressure tube, or is there significant heat removal by other means such as the cover gas?

\section{Answer:}

Yes, graphite heat is $5.5 \%$ of the core thermal power. Most of the heat is removed by the primary coolant in the pressure tube (channel) through the "hard contact" graphite rings (Figure 5). It is nearly $80 \%$ to $85 \%$ of all graphite heat. The rest of it is removed by the control rod coolant in their channels.

The gas circulation $(70 \%$ to $90 \% \mathrm{He} 2+10 \%$ to $30 \%$ N2) almost does not remove graphite heat. It only creates the condition for its effective removal (the so called "heat bridge"). 


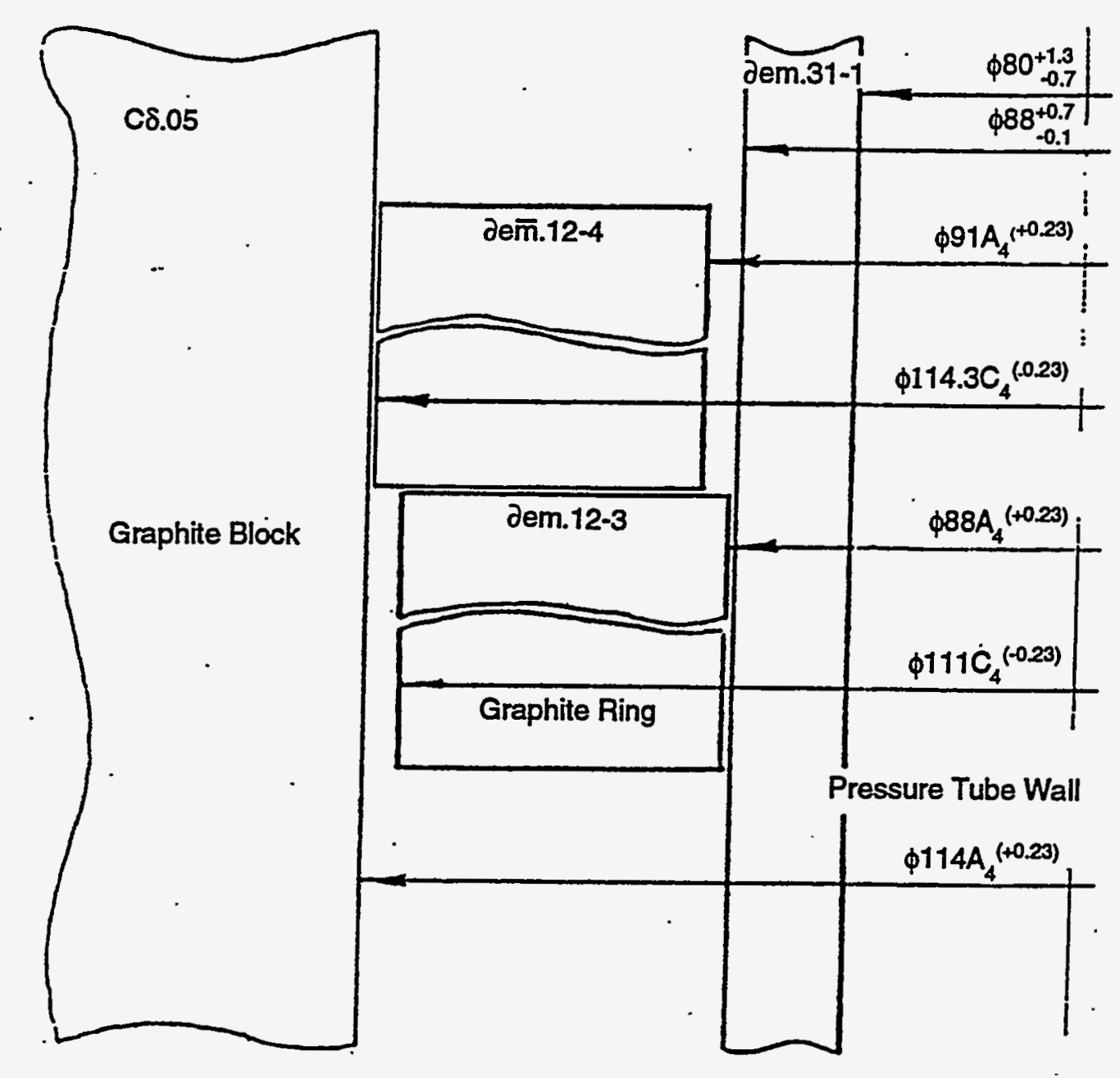

Figure 5. Graphite Rings and the Pressure Tube Interface 


\section{Group III Questions - RBMK Operations}

Question 1: How is steam drum level measured, and where are the instrumentation taps located on the drum?

Answer: ·

The device for steam drum level measurement includes a level vessel, signal (impulse) tubes, differential manometer, and electric instrumentation.

The level vessel is located in the "cool" room and connected to the steam drum through the room wall. The signal tubes $(50 \mathrm{~mm})$ connect the drum "steam" side with the vessel top, and drum "water" side with the vessel bottom. The level vessel consists of two chambers. The internal chamber is filled to the top due to natural circulation.

The external chamber level is connected with the lowest part of the drum. Signal tubes are connected to the differential manometer from the bottom internal chamber " + " output and from the bottom external chamber "-" output. Level difference between internal and external chambers determines drum level. Figure 6 illustrates the principle of measurement.

There are two types of this device. A "big detector" activates the control of drum level and emergency protection system (scram, fast power decrease, ECCS). Its scale is $+1-800 \mathrm{~mm}$ from the drum geometrical axis. It also measures water inventory in the primary circuit.

A "small detector" measures the level of steam-water mixture on the drum grill. It is an indicator of steam moisture that determines the operational limit of drum level. All level instrumentation measure weight level because the temperature in the room is normal where level vessel is located. This factor provides for the natural circulation and excludes the froth influence.

Question 2: $\quad$ How is drum level controlled? We assume that it is controlled by the feedwater return. Is the control one element (by level only) or three elements (level, plus steam and feedwater flow balance)? What type of control is it (proportional, proportional plus reset, or lead-lag)? We assume it is one element (level) and proportional plus reset. What are the controller gains?

\section{Answer:}

(Figures 7-12 help to answer drum level questions.) Yes, drum level is controlled by the feedwater return. Over $20 \%$ of control signal power is the sum of deviation from drum level rate (the level rate 


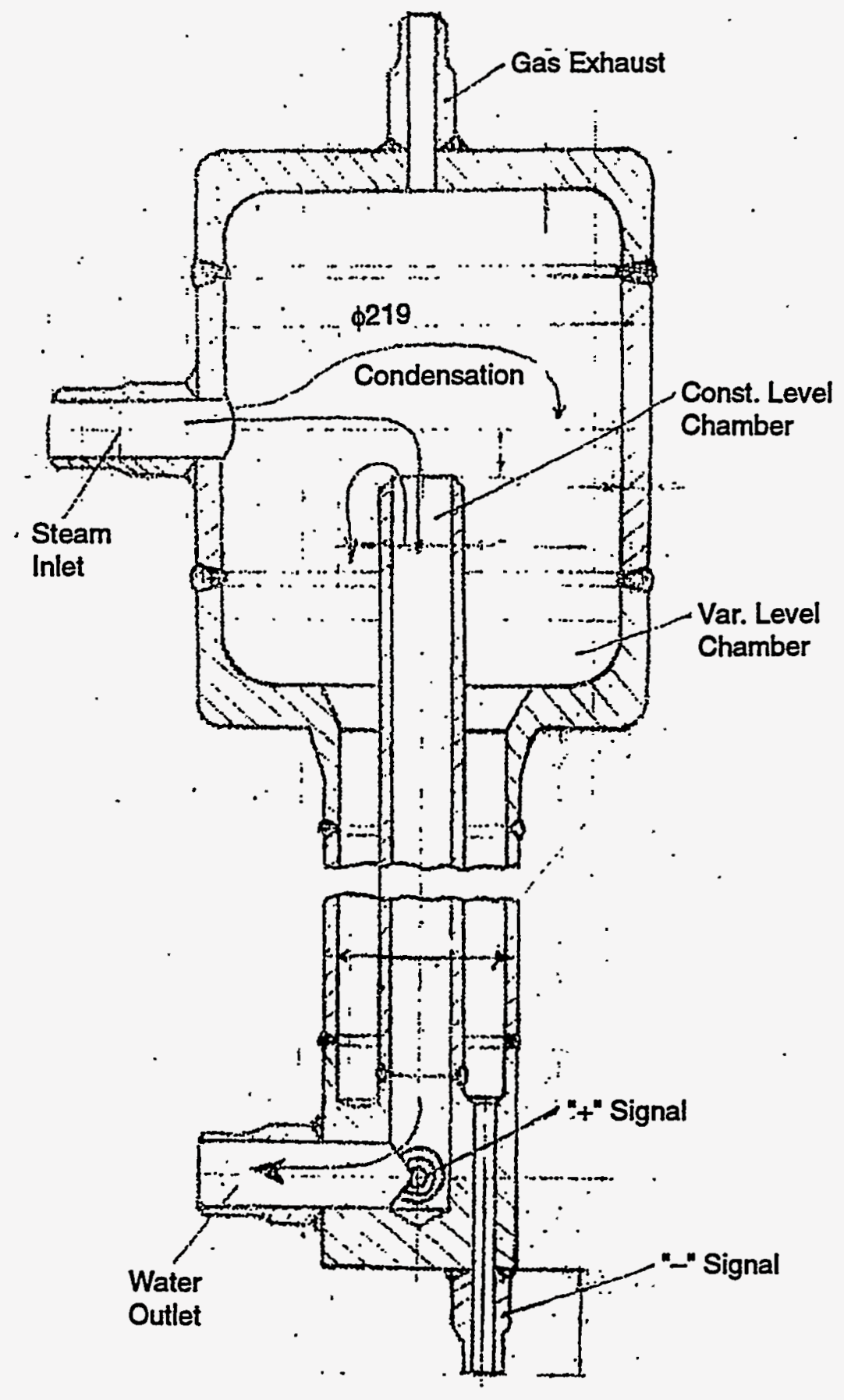

Figure 6. Level Vessel for First Generation Units ( $\pm 800 \mathrm{~mm}, \pm 315 \mathrm{~mm}$ ) 


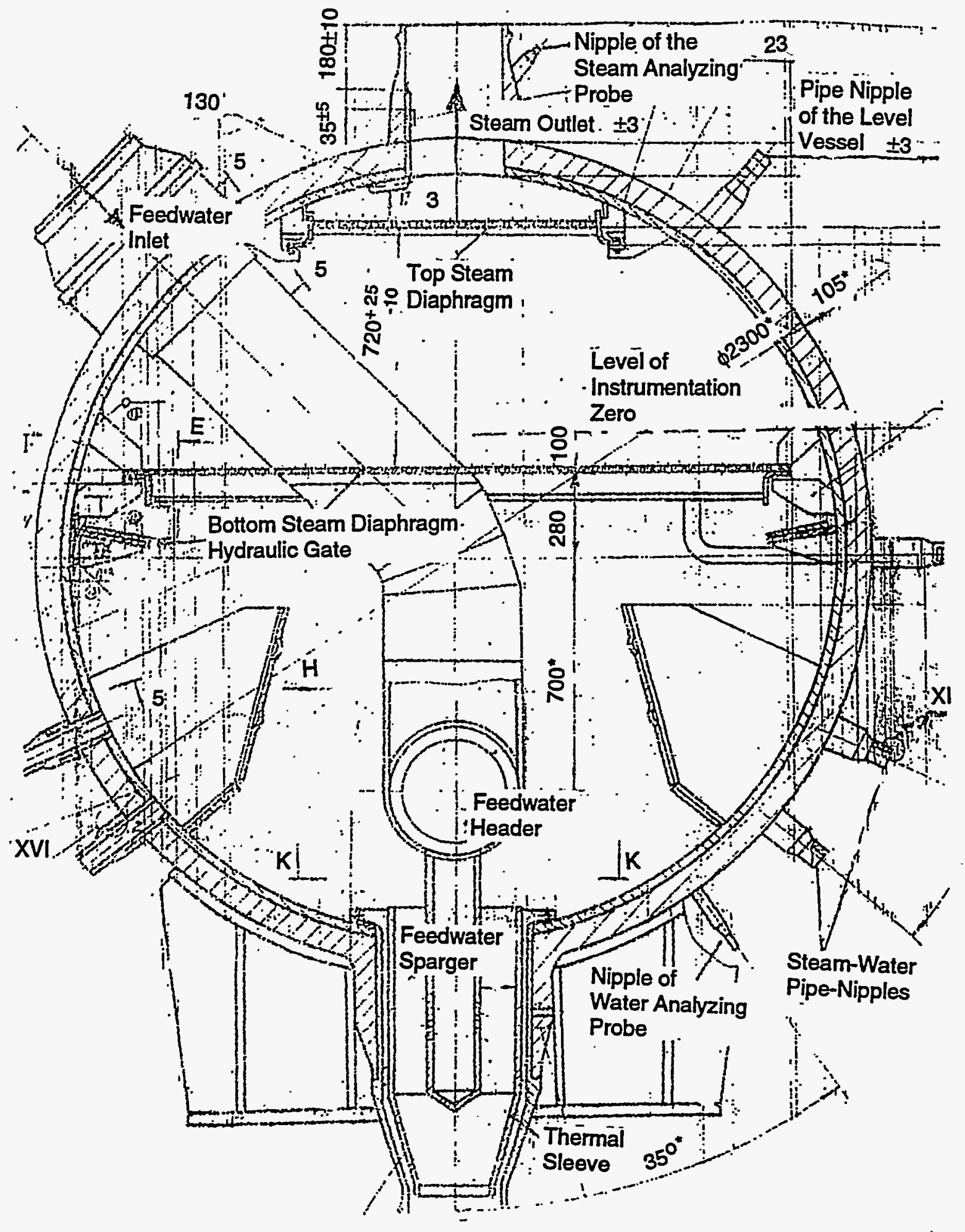

Figure 7. The Internals of the Steam Drum for First Generation Units 


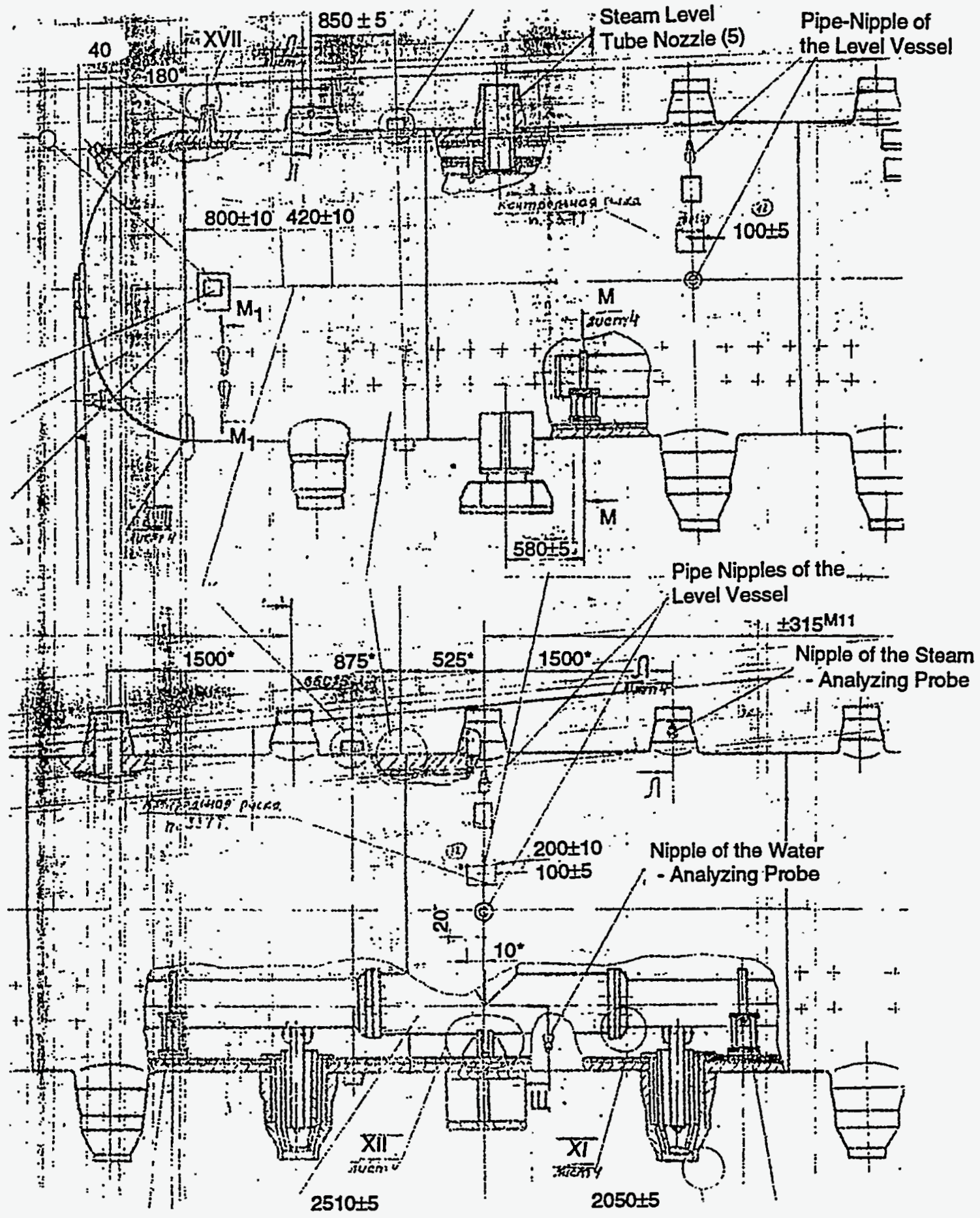

Figure 8. Internals of Steam Drum 


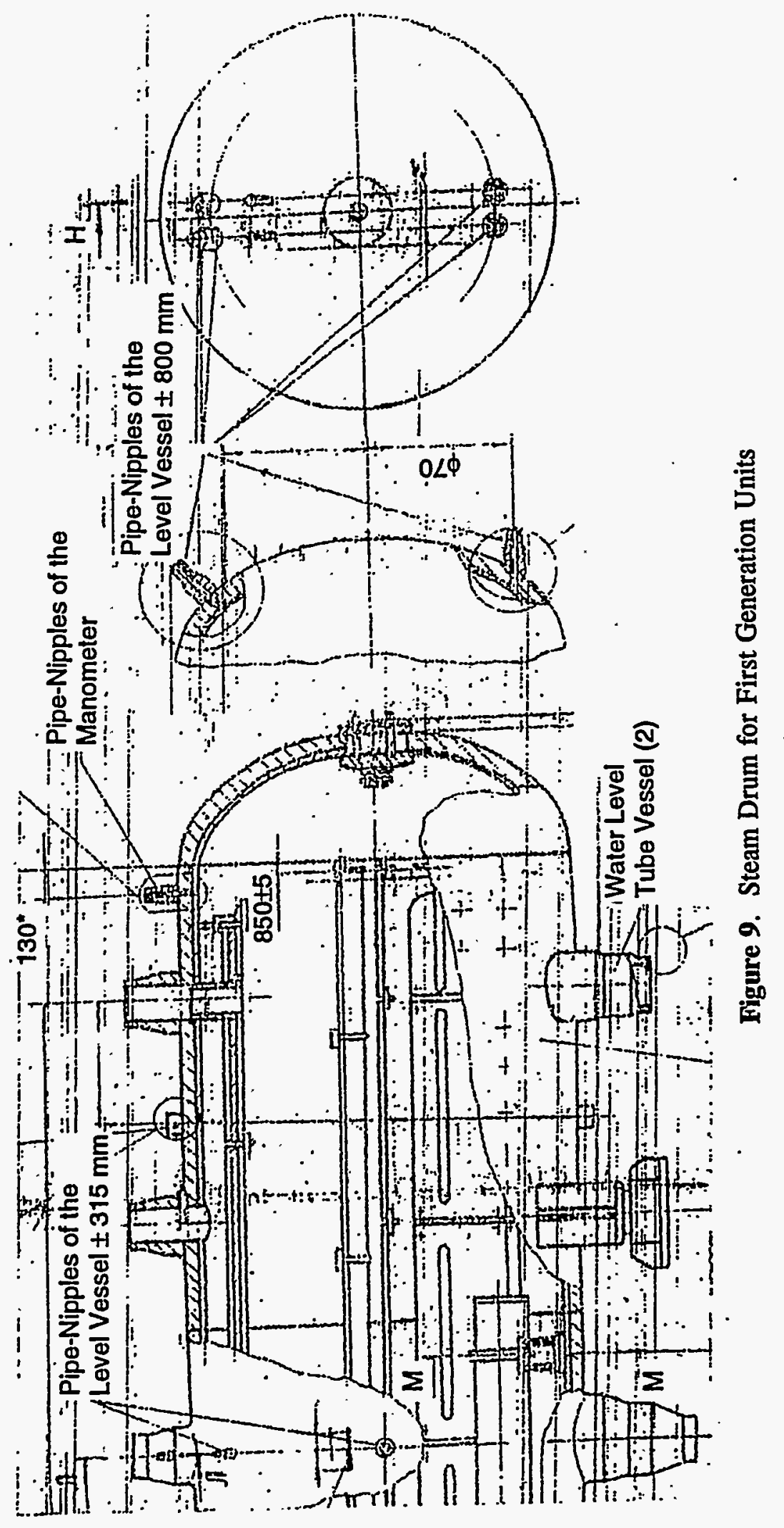




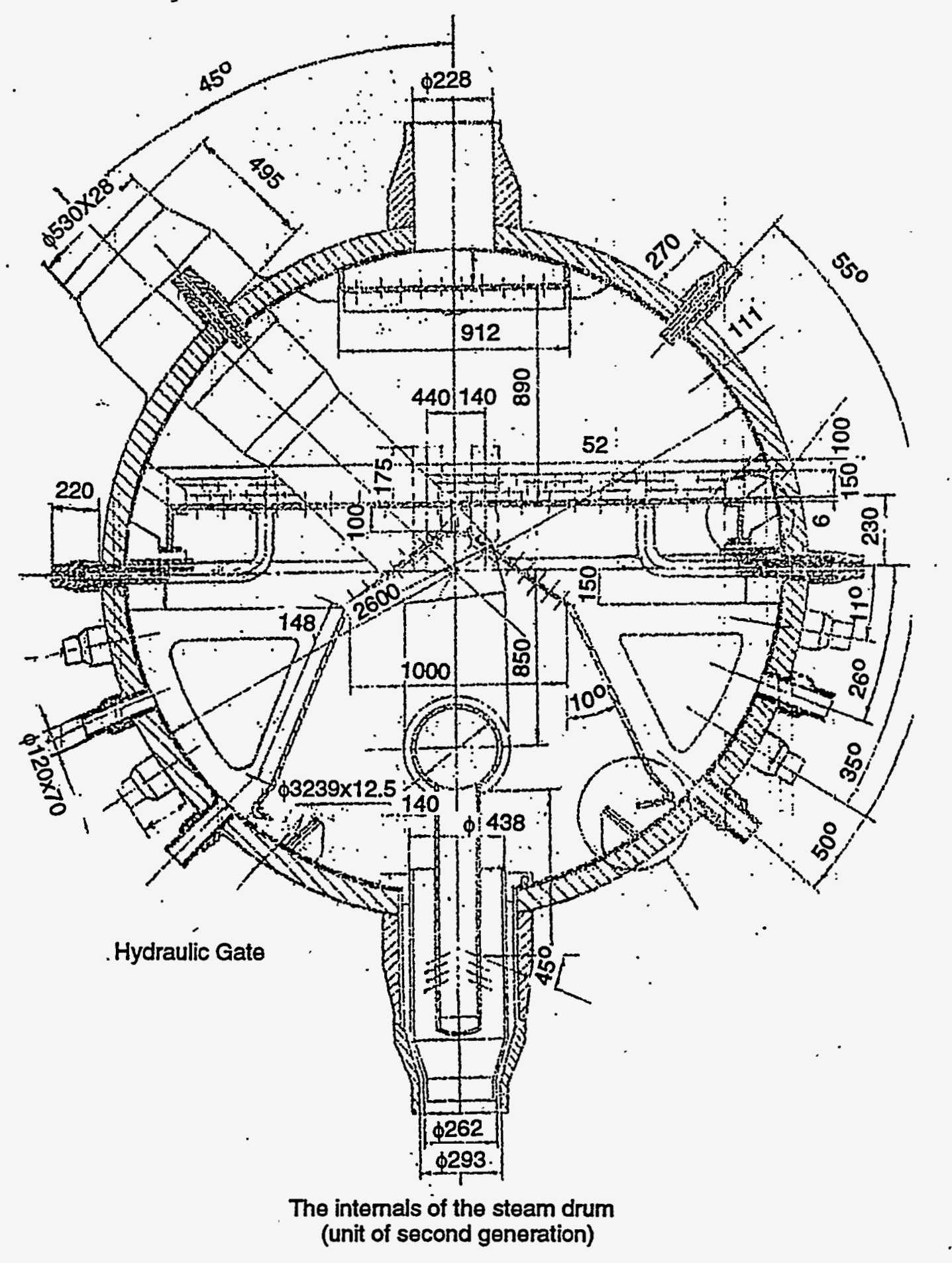

Figure 10. The Internals of the Steam Drum for Second Generation Units 


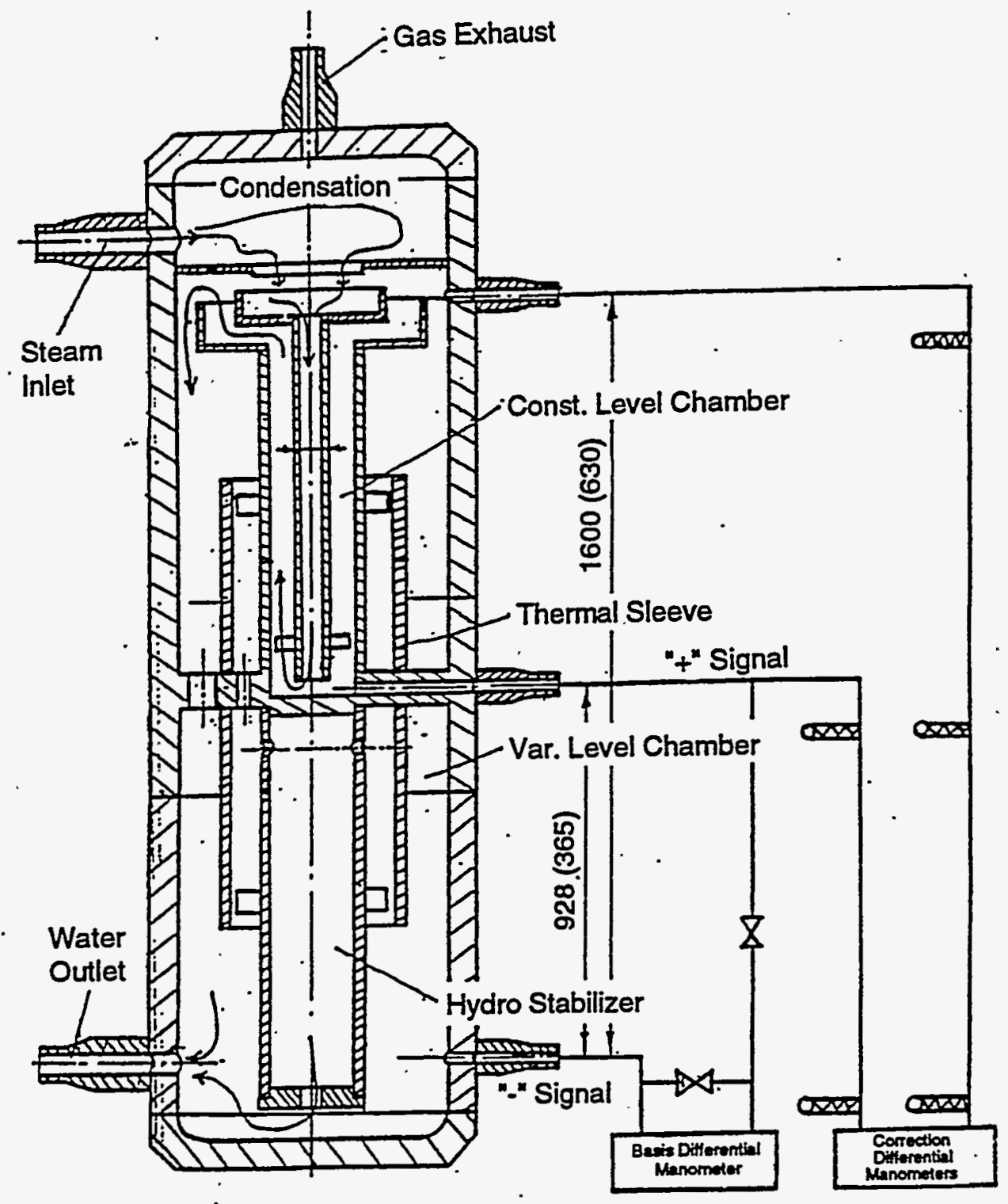

Figure 11. Level Vessel for Second Generation Units $( \pm 800 \mathrm{~mm}, \pm 315 \mathrm{~mm}$ ) 


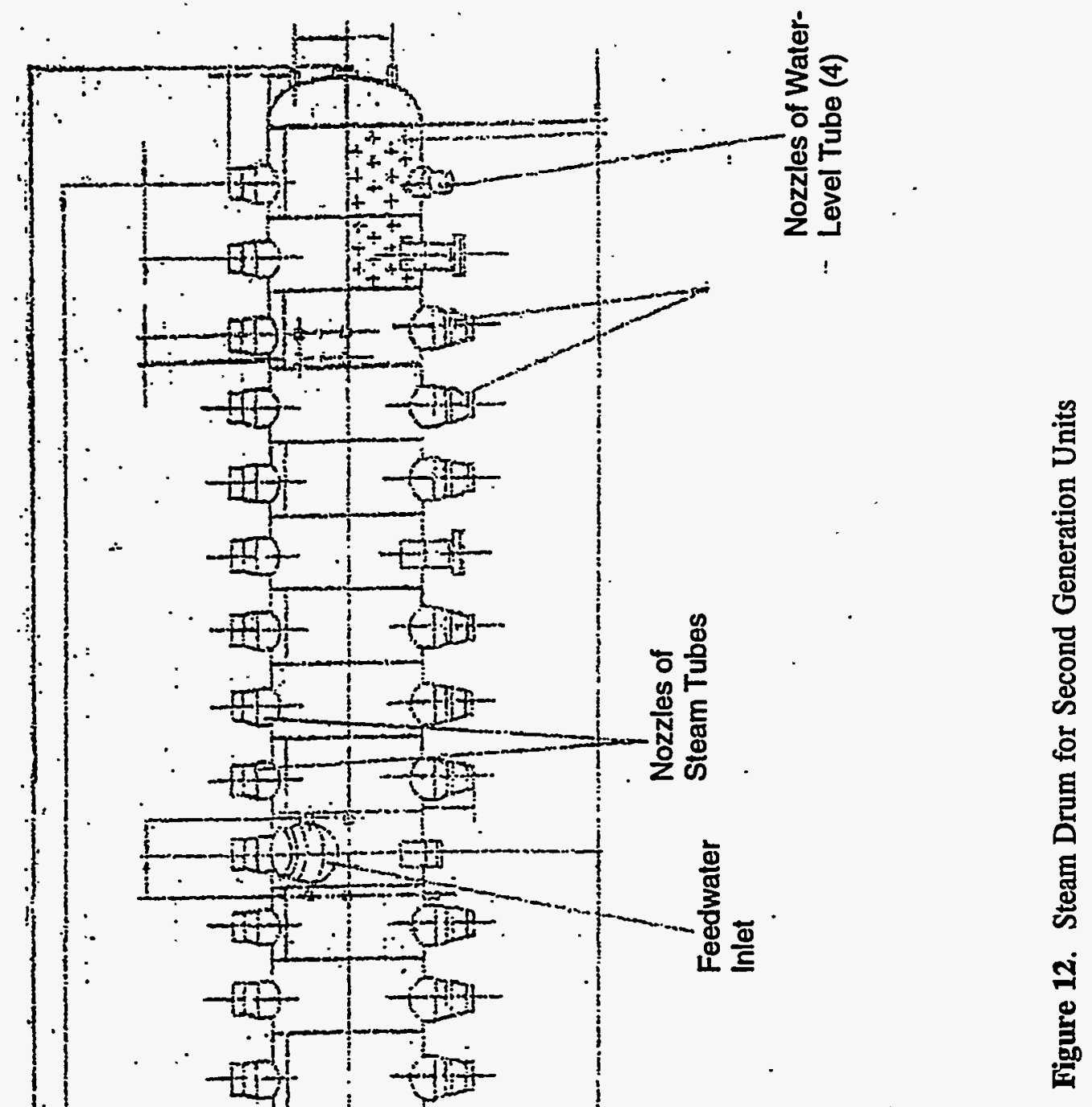

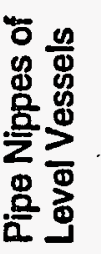

on

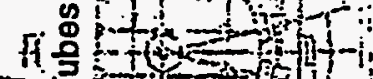

क $P$ i

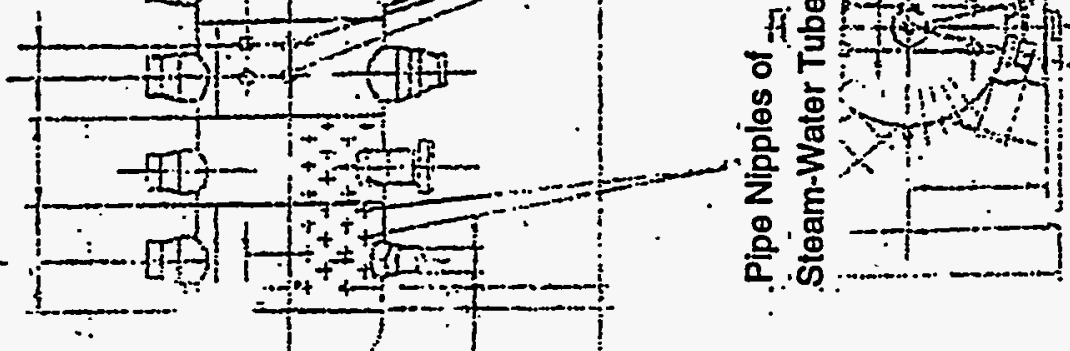


is established in the control room) and steam-feedwater flow balance. Each of the primary circuits has its own drum level circuits level and flow detectors, control, and execution units with 2 control valves $(300 \mathrm{~mm})$.

One control valve is switched into automatic mode of control through control unit, and the manual control valve is activated from the control room during constant power or slow power increase/decrease.

During fast transients or fast control unloading (1 turbine trip out of 2,1 main circulation pump trip out of 3, drum level decrease to the setpoint of $500 \mathrm{~mm}$, feedwater flow decrease to $70 \%$ from the initial rate), the second control valve automatically switches into automatic control along with the first one.

The control type is proportional plus floating (isodrom control). Controller gains for level and flow signals and isodrom time are established before the first power unit actuation and is corrected during start-up and after special testing.

The gains are established to be the main component of steam-feedwater balance during the fast process and the drum level deviation during the slow process.

At $20 \%$ power, the control signal is only one-element (drum level) because during the start-up power increase from $0 \%$ to $20 \%$ there exists a high error-probability in steam flow measurements.

Drum level is controlled by the special $(150 \mathrm{~mm})$ feedwater control valve (in each loop).

\section{Question 3: What are the feedwater return pump characteristics (pump curve)?}

\section{Answer:}

Figure 13 answers this question. 


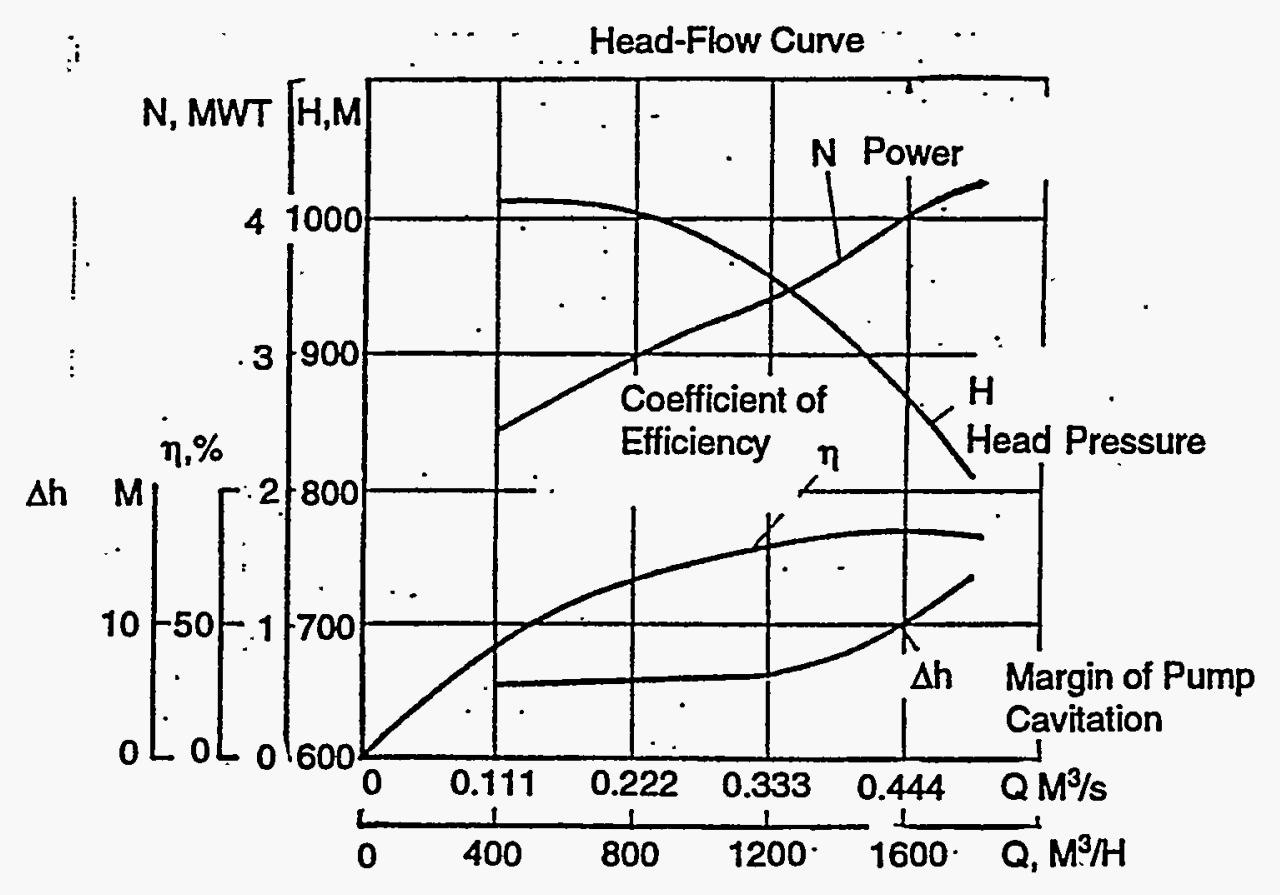

Figure 13. Feedwater Pump Curve

Question 4: . How is makeup controlled to the reactor loop (for coolant expansion, contraction, and loss of inventory) during full reactor power? Where is makeup injected into the reactor loop (is it through the feedwater return, or somewhere else)?

Answer:

. The answer is clear from schemes (Figures 14-16). 


\section{Key: Marking Schemes of NPP RBMK-1000}

- Simple Heat Scheme

- Makeup and Outflow Scheme

- Simple ECCS Scheme

1. Core

2. Steam drums (4)

3. Turbine high pressure part $(1 \times 2)$

4. Steam moisture separators $(4 \times 2)$

5. Reheaters ( $4 \times 2$ )

6. Turbine low pressure part $(4 \times 2)$

7. (No description)

8. Condensers $(4 \times 2)$

9, 11. Condensate pumps $(3 \times 2+3 \times 2)$

10. Condensate

12. Heat exchangers (5-step x 2)

13. (No description)

14. . Deaerators (4)

15. ECCS feedwater pumps (3)

16. Feedwater pumps (5)

17. (No description)

18. (No description)

19. Reactor water cleaning system (1)

20. Non-regenerative exchangers (1 or 2 for different units)

21. Regenerative heat exchanger (1)

22. ECCS heat exchangers of emergency pumps of damaged loop (3) (available only for second generation units)

23. ECCS emergency pumps of damaged loop (6) (available only for second generation units)

24. ECCS emergency pumps of intact loop (3) (available only for second generation units).

25. Storage tanks

26. ECCS hydro-pneumatic accumulators (water inventory for first generation units $30 \times 1+30 \mathrm{~m}^{3}$, water inventory for second generation units $-60 \times 2=120 \mathrm{~m}^{3}$ )

27. Cleaning water makeup pumps (3)

28. Main circulation pumps (3)

29. Accumulator for the MCP hydraulic seal system water (1) (available only for first generation units)

30. Pumps of the MCP hydraulic seal system water (4) (available only for first generation units)

31. Disbalance water tanks of the turbine area (for hydrotesting)

32. Disbalance water tank of the primary circuit 
33. Trap water tanks

34. Evaporator cleaners

35. Ion-exchanger cleaners

36. Makeup pumps of the turbine area

37. Low pressure makeup pump of the primary circuit

38. Suppression pool (available only for second generation units)

39. ECCS fast-acting valve

40. Pressure header (2)

41. Group distribution headers (2)

42. Flow limiters (44)

\section{Makeup or Outflow}

1. Condenser operational makeup

2. Main circulation pump operational makeup

(available only for second generation units)

3. Degerator makeup in case of deviation during operation

4. Primary circuit makeup during outage

5. Emergency feedwater pumps makeup during emergency and outage

6. Group distribution header emergency makeup from hydro-accumulators of ECCS

7. Group distribution header emergency makeup from ECCS emergency pumps of damaged loop (available only for second generation units)

8. GDH emergency makeup from ECCS emergency pumps of intact loop

(available only for second generation units)

9. Outflow from the primary circuit after hydrotesting during outage

10. Outflow from the turbine area during outage or operation 


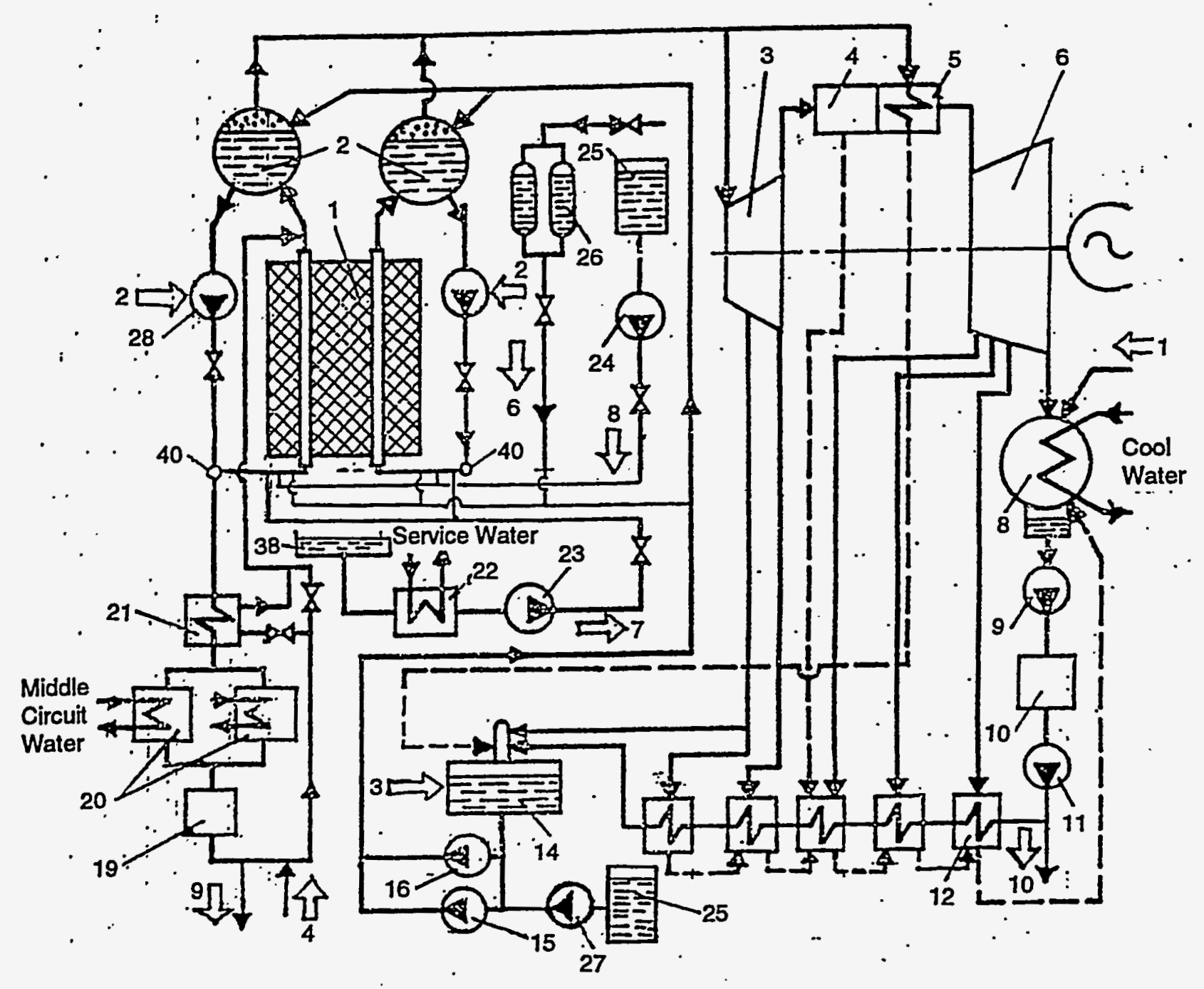

Figure 14. Simple Heat Scheme (see key) 


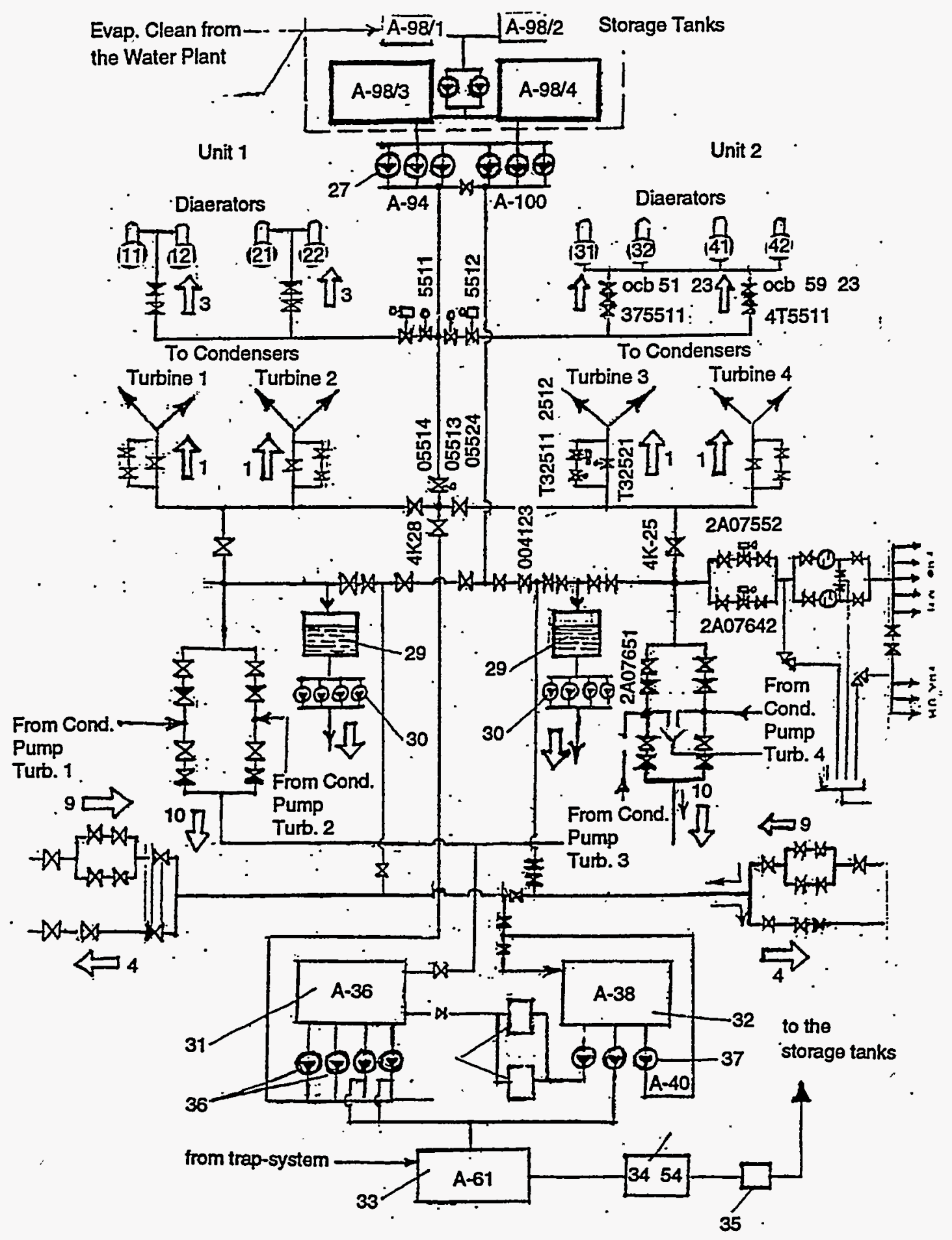

Figure 15. Makeup and Outflow Scheme (see key) 


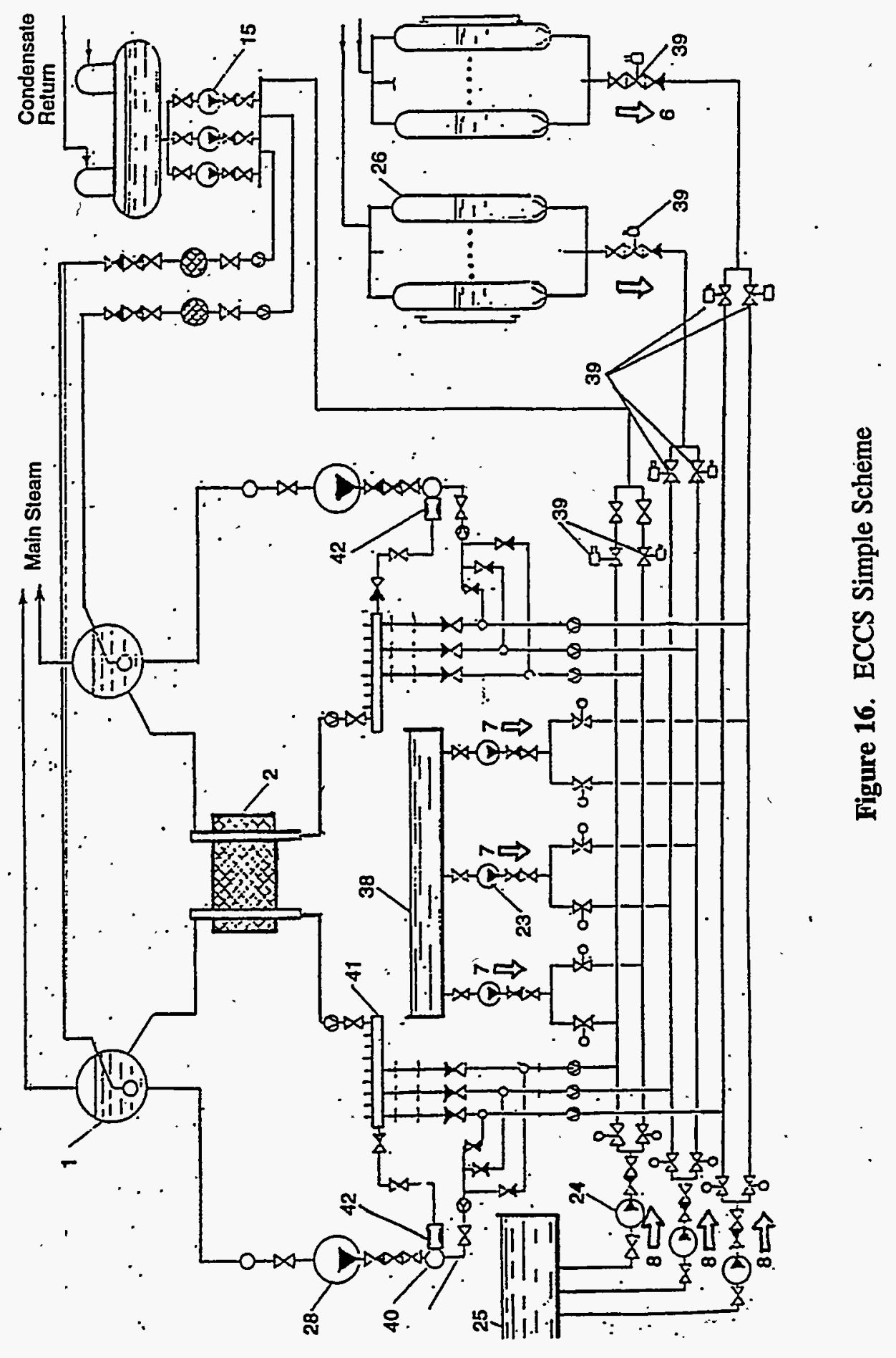


Question 5: What is the maximum turbine bypass available? How is it controlled?

Answer:

The total capacity of turbine bypass per each unit is $750 \times 4=3000 \mathrm{t} / \mathrm{hr}$ ( 2 bypasses per 1 turbine, 4 per 1 unit). Turbine bypass actuates in case of

- drum pressure increase to 72 At

- shutdown of one turbine (if generator power is larger than $250 \mathrm{MWe}$ ).

Bypass actuation is blocked in case of

- condenser vacuum is $5600 \mathrm{~mm} \mathrm{Hg}$

- failure of the discharge from a turbine to condenser cooling system (cooling water pressure is $\leq 8 \mathrm{At})$.

Question 6: How is steam drum pressure controlled? Does it include reactor power and turbine load feedback?

Answer:

Drum pressure is controlled by the turbine load feedback. The indication is drum pressure, the actuator is a turbine control valve. The control signal indicates the deviation from drum pressure rate (the pressure rate is established in the control room).

One turbine control valve is switched into automatic mode of control through the control automation, and another valve, the manual valve, is activated from the control room during the mode of constant power or slow power increase/decrease.

During fast controlled unloading (in case of 1 main circulation pump trip out of 3, or drum level decrease to setpoint of $500 \mathrm{~mm}$, or feedwater flow decrease to $70 \%$ from the initial rate), the second turbine control valve automatically switches into automatic control along with the first one.

The control type is proportional plus floating (isodrom control). 
Question 7: What are the ECCS pump characteristics? What is the supply/demand curve for the $E C C S$ to the point of injection to the reactor loop?

Answer:

Figures 17-19 help to explain this question. The design basis accident (DBA) of RBMK-1000 is the accident initiating abrupt break of one of the primary circuit tubes:

- the downcomer from drum to the suction header (300 mm bore) of main circulation pumps (MCP) for first generation units

- the pressure header (1000 mm bore) of MCPs with one GDH non-closing check valve for second generation units.

It is postulated that water and steam flow through both fully free sections. ECCS is to provide core cooling so as to ensure the following:

- the fuel element zirconium cover temperature $\leq 1200^{\circ} \mathrm{C}$

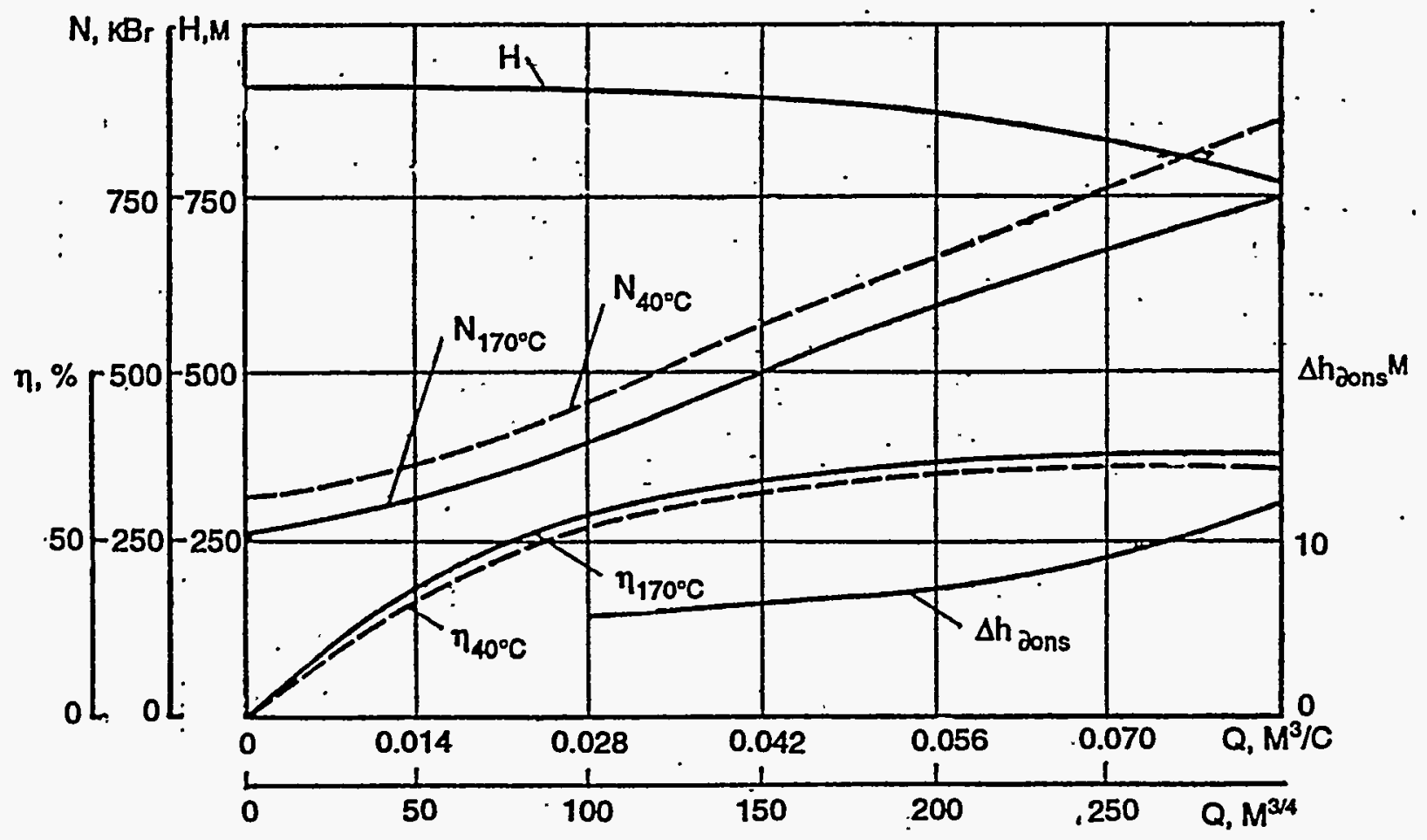

Figure 17. ECCS Pump Characteristics 


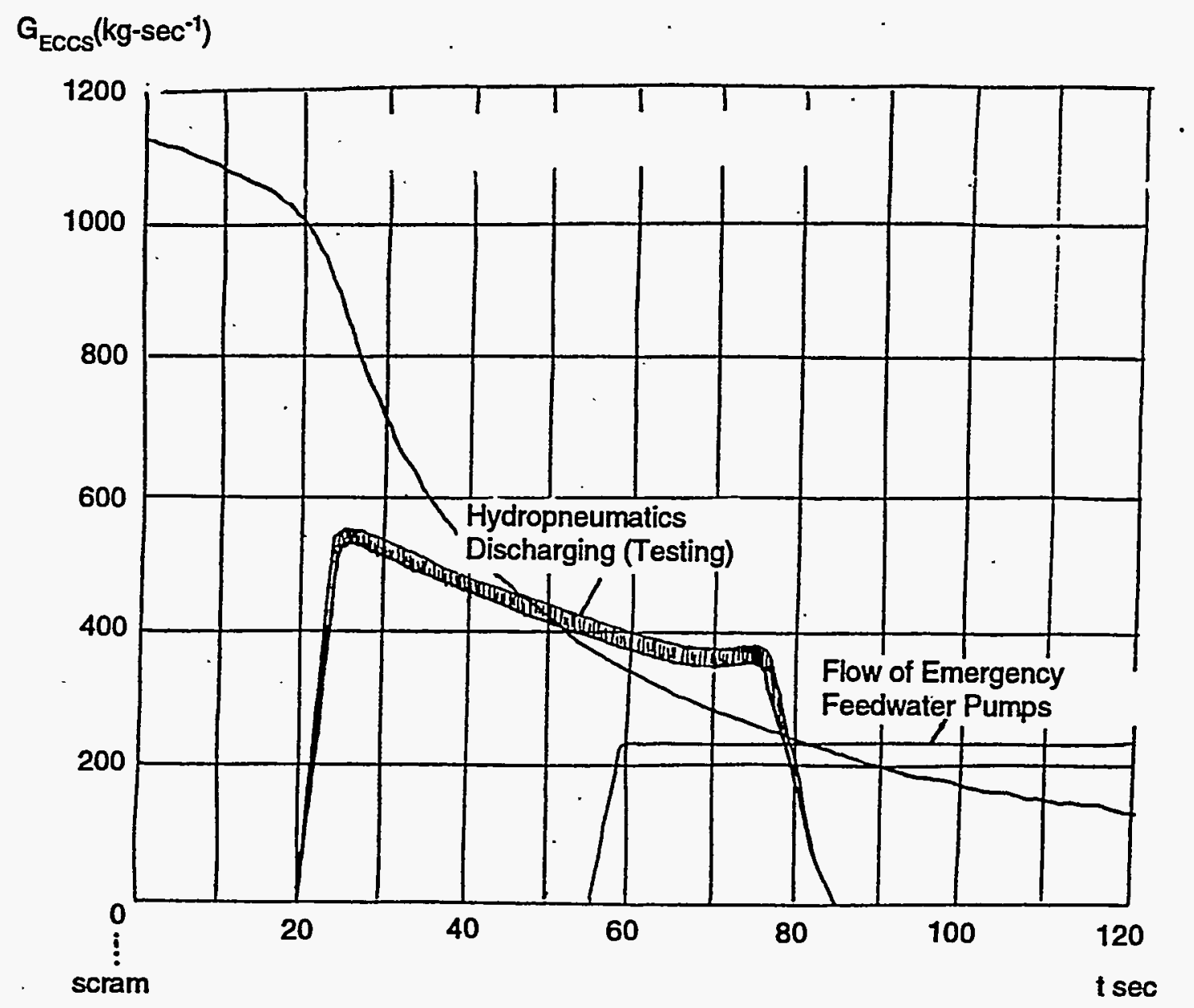

Figure 18. The Supply/Demand Curve for the ECCS of First Generation Units (break of $300 \mathrm{~mm}$ tube). Source: ECCS Testing (Kursk NPP). 


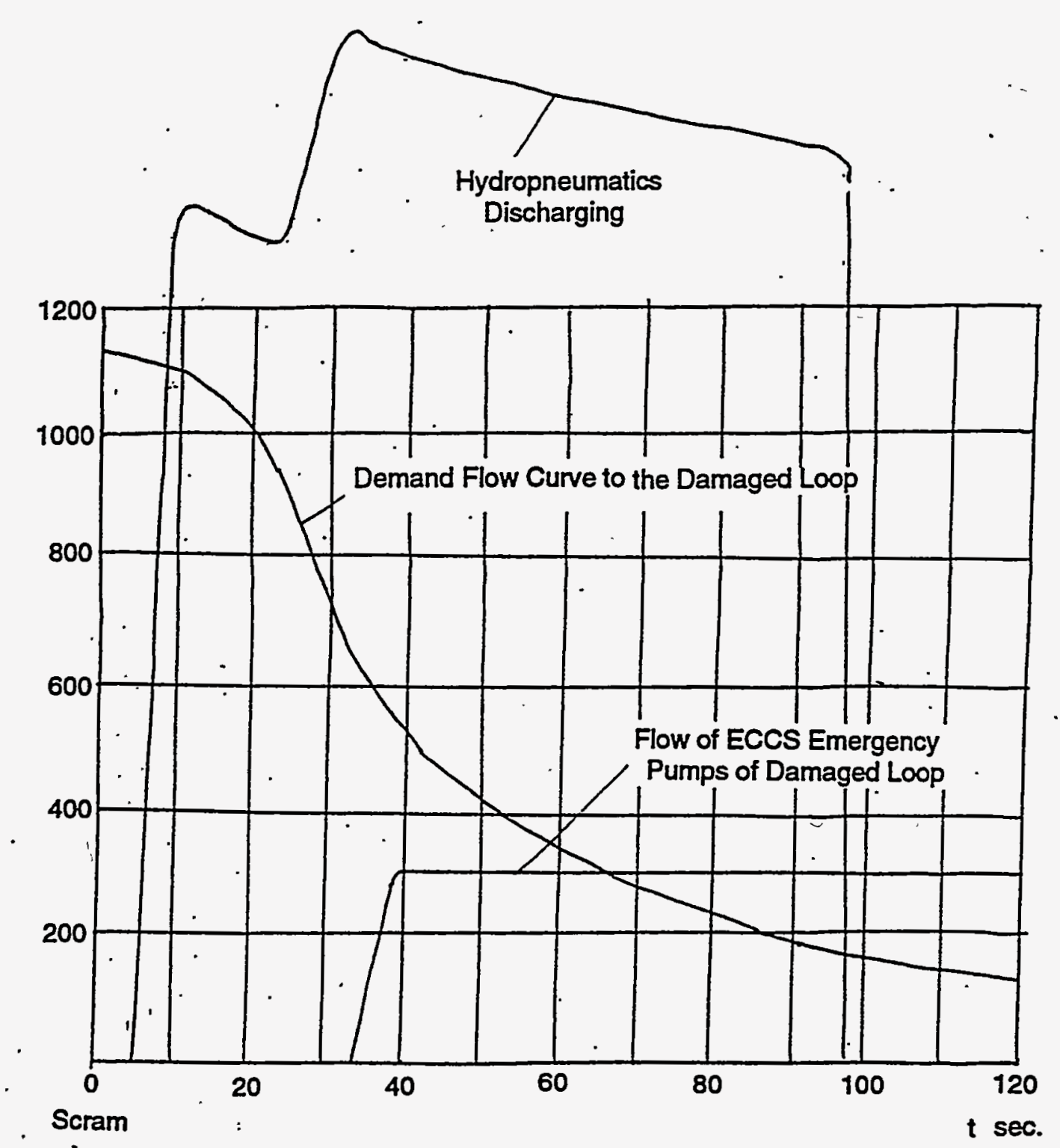

Figure 19. The Supply/Demand Curve for the ECCS of Second Generation Units (break of $1000 \mathrm{~mm}$ ). Source: Technical Safety Assurance Kursk NPP 2 Stage. 
- the local oxidation of zirconium cover of initial wall thickness $\leq 18 \%$

- the zirconium activated in chemical reaction is $\leq 1 \%$ of zirconium mass of all bundles in one group distribution header. (General Rules on Safety - ON5-82.)

Additionally, channel wall temperature is to be $5600^{\circ} \mathrm{C}$ with the permissible exceedance during $\leq 100 \mathrm{sec}$ (Safety Commission of Interministry Council - 05.05.76).

Question 8: $\quad$ What is the full open area of the inlet valve (to each fuel tube)? A source indicates that it is $234 \mathrm{~mm}^{2}\left(0.000234 \mathrm{~m}^{2}\right)$. This seems slightly small.

Answer:

Figures 20 and 21 show the mistake. Right ratio $\sim 0.0008 \mathrm{~m}^{2}$. 

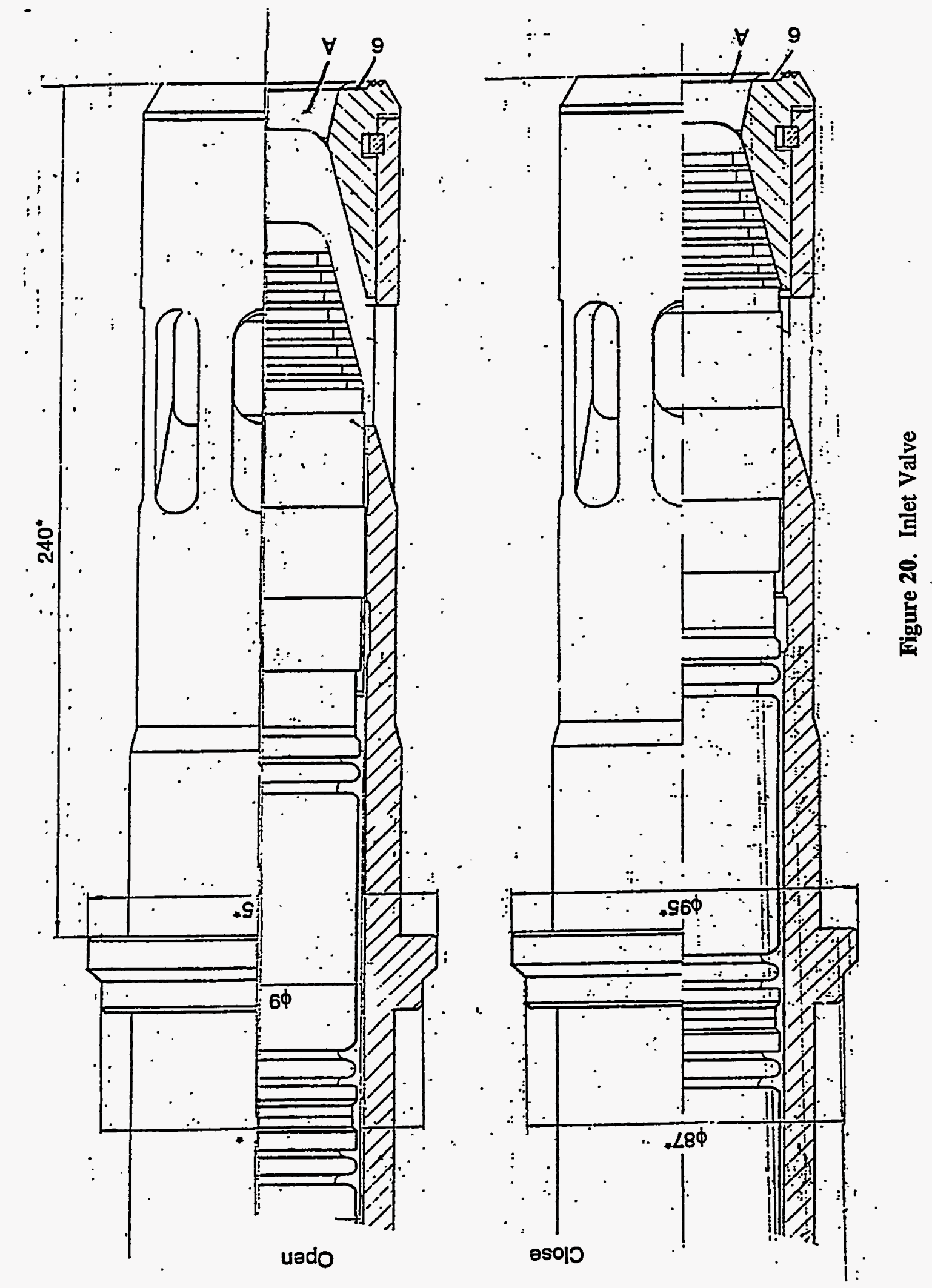


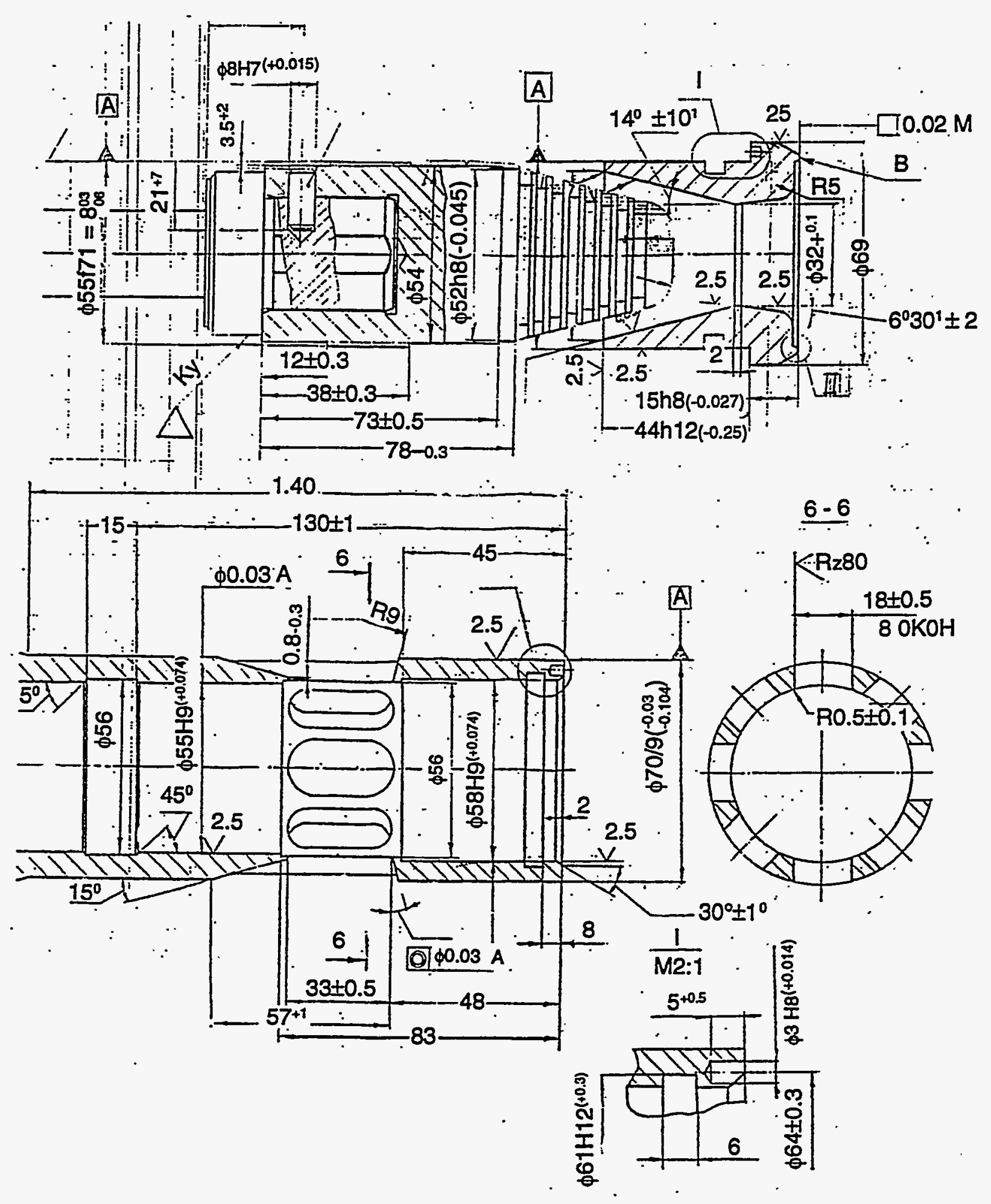

Figure 21. Inlet Valve Dimensiọns 


\section{Distribution}

No. of

Copies

\section{OFFSITE}

12 DOE/Office of Scientific and Technical Information

Dr. Sol Rosen, Director International Programs Division Office of Program Support Assistant Secretary for Nuclear Energy Department of Energy Washington, DC 20545

Dr. Anthony F. Czajkowski, Director Office of Arms Control (AN-10) U.S. Department of Energy 1000 Independence Avenue, SW Washington, DC 20585

Ms. Carol E. Kessler Deputy Senior Coordinator for Reactor Safety Assistance

U.S. Department of State Washington, DC 20520

\section{FOREIGN}

Dr. Leonid Bolshov, Director Institute of Nuclear Safety Russian Academy of Sciences 52.B. Tulskaya Moscow, Russia 113191

Dr. Nikolai N. Ponomarev-Stepnoi, First Deputy Director

I.V. Kurchatov Institute of Atomic Energy Kurchatov Square

Moscow, Russia 123182
No. of

Copies

Dr. Vladimir Asmolov, Director

Nuclear Safety Institute

I.V. Kurchatov Institute of Atomic Energy

Kurchatov Square 1

Moscow, Russia 123182

\section{ONSITE}

DOE Richland Field Office

Richard B. Goranson

Laboratory Management Division

K8-50, EESB/1622/RCHN

23 Pacific Northwest Laboratory

E. L. Benjamin, K8-33

L. R. Dodd, K8-31

J. L. Fuller, K6-48

S. W. Heaberlin, K8-34

A. T. Luksic, K8-41

S. L. McKay, K8-31

J. P. McNeese, K6-50

G. H. Meriwether, K8-34

K. R. Mikkelson, K8-33

R. L. Moffit, K8-43

R. D. Nelson, BWO

D. F. Newman, K8-44

A. W. Prichard, K8-34

B. D. Reid, K8-34

B. E. Schmitt, K8-34

G. V. Tsiklauri, K8-34

C. E. Willingham, K8-41

Publishing Coordination

Technical Report Files (5) 